\title{
Explaining Inequality and Poverty Reduction in Bolivia
}




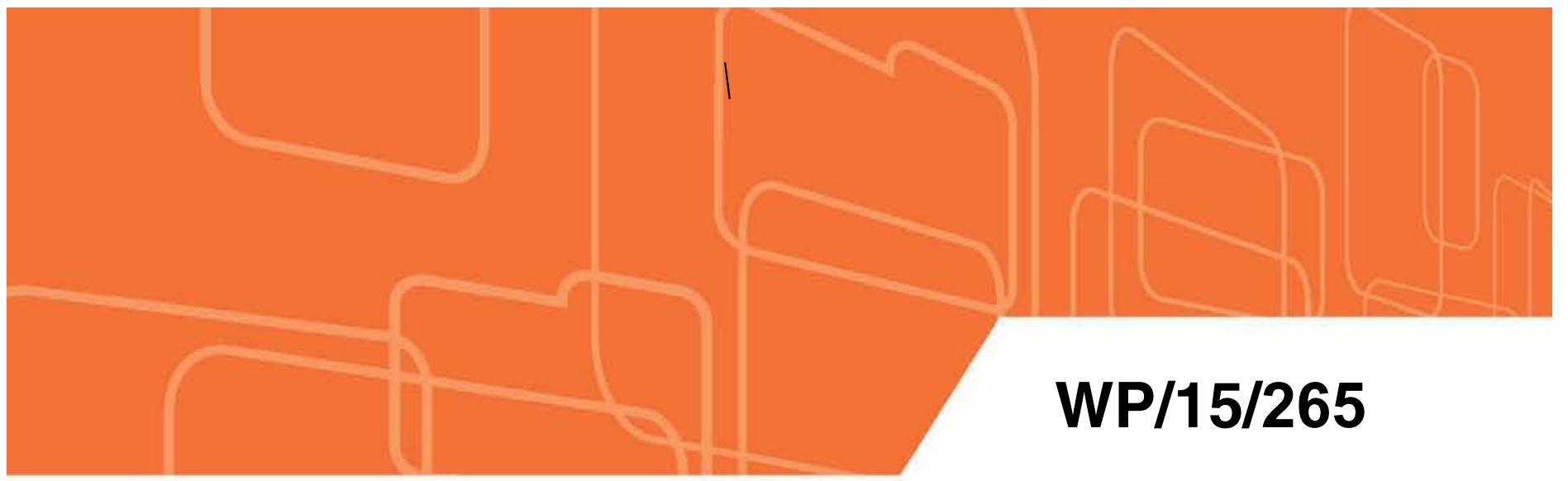

\title{
IMF Working Paper
}

\section{Explaining Inequality and Poverty Reduction in Bolivia}

\author{
by Jose P Mauricio Vargas and Santiago Garriga
}

IMF Working Papers describe research in progress by the author(s) and are published to elicit comments and to encourage debate. The views expressed in IMF Working Papers are those of the author(s) and do not necessarily represent the views of the IMF, its Executive Board, or IMF management. 


\title{
IMF Working Paper
}

Western Hemisphere Department

\section{"Explaining Inequality and Poverty Reduction in Bolivia" \\ Prepared by Mauricio Vargas and Santiago Garriga ${ }^{1}$}

Authorized for distribution by Krishna Srinivasan

December 2015

\section{IMF Working Papers describe research in progress by the author(s) and are published to elicit comments and to encourage debate. The views expressed in IMF Working Papers are those of the author(s) and do not necessarily represent the views of the IMF, its Executive Board, or IMF management.}

\begin{abstract}
We investigate the factors driving Bolivia's success in reducing inequality and poverty during the last 15 years. Our evidence suggests that the reduction was driven mainly by labor income growth at the bottom end of the income distribution. Increases in non-labor income (rents, transfers, remittances) also played a role, but a smaller one, although the introduction of Renta Dignidad has made a big difference for the elderly poor. Labor income increases were concentrated in the informal, low-skilled service and manufacturing sectors. As the gains from the commodity boom go into reverse, and the fiscal envelope becomes much tighter, it will be essential that labor and social policies are well designed and targeted to preserve the poverty and inequality reduction of the last 15 years.

JEL Classification Numbers: D63, I32.

Keywords: Inequality, Poverty, Bolivia

Author’s E-Mail Address: MVargas@imf.org
\end{abstract}

\footnotetext{
${ }^{1}$ I would like to thank participants at seminars organized by the Ministry of Finance in La Paz in September 2015 and at the LACEA annual meeting in Santa Cruz on October 15, 2015. I also thank Ravi Balakrishnan, Siddharth Kothari and other IMF colleagues for their comments and suggestions.
} 
I. Introduction

II. Evolution of Inequality and Poverty in Bolivia: A Comparative Analysis ......................... $\underline{6}$

III. Potential Effects of Macro Trends and Public Policy .......................................................

IV. Explaining Inequality and Poverty from Micro Data …........................................ 13

A. Comparing Official and SEDLAC Data .................................................... 13

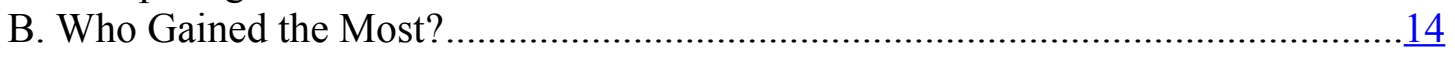

C. Inequality and Poverty Decompositions ….................................................

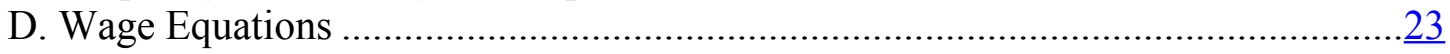

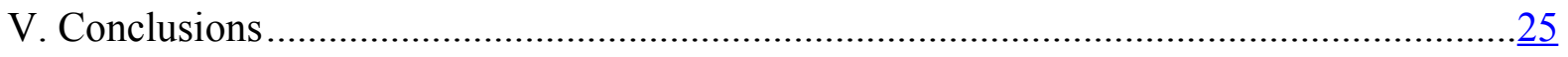

Tables

1. Composition of the Household Total Income per Capita (Selected Years) .......................15

2. Potential Effects of Renta Dignidad .....................................................................16

3. Growth Rate of the Number of People Earning a Greater than Zero Non-Labor Income...17

4. Real Labor Income per Capita (in Real Bs. and Growth Rate) .....................................22

5. Econometric Model-(Mincer Equation for 2001, 2006, and 2013) 1/ ............................24

Figures

1. Gini Index Evolution for Select Group of Countries and Bolivia ...................................... $\underline{6}$

2. Inequality in LAC: Comparative Inequality Measures ................................................

3. Growth, Changes in Gini Coefficient (by educational level) and Wage gap Between early

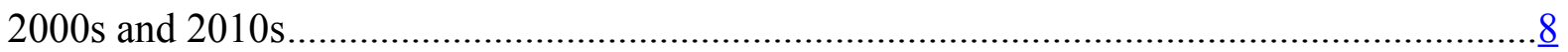

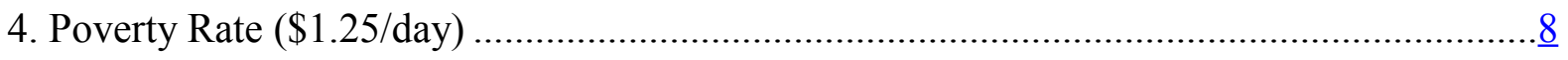

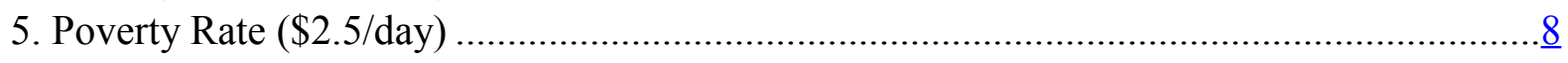

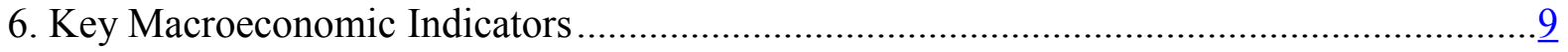

7. Composition of GDP by Expenditure .................................................................

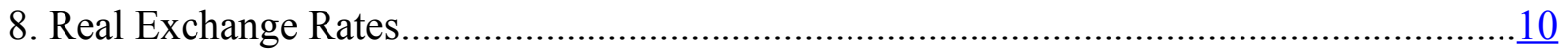

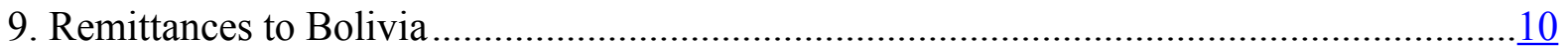

10. Real Minimum Wages in the Region...................................................................11

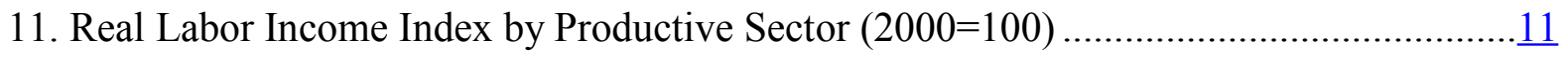

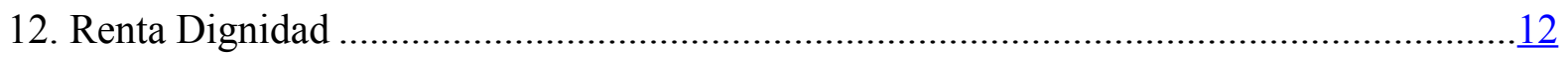

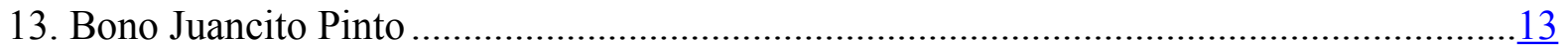

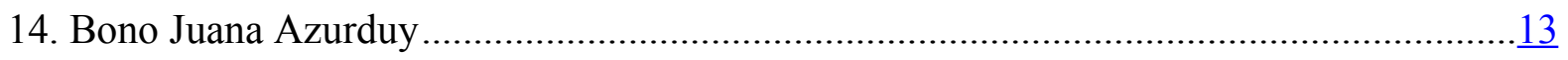

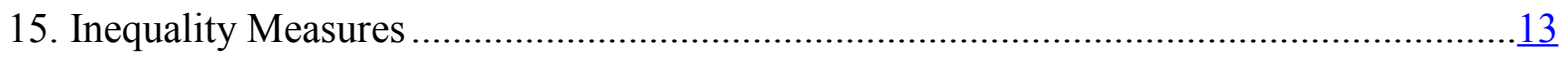

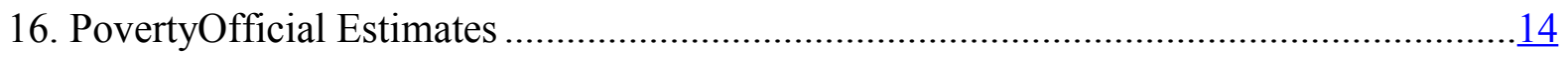

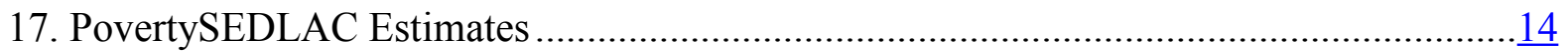


18. Income Distribution for Selected Years (in Real Bs.) ............................................... 15

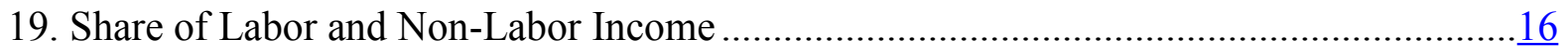

20. Bolivia: Indices of Real Labor Income per Capit .....................................................18

21. Bolivia: Indices of Real Non-Labor Income per Capita ............................................ 19

22. Datt-Ravallion Decomposition of Changes in Poverty ..................................................20

23. Decomposition of Reductions in Poverty and Inequality by Education Level .................21

24. Decomposition of Reductions in Poverty and Inequality by Labor Condition..................22

25. Decomposition of reductions in Poverty and Inequality by Activity Sector (2007-2013) $\underline{23}$

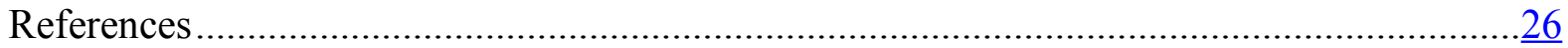

Appendixes

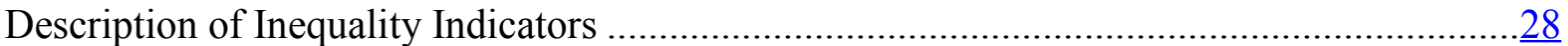




\section{INTRODUCTION}

Inequality and poverty are not new issues. However, in response to the global financial crisis, they have become key priorities for policymakers throughout the world. And Bolivia, one of the poorest countries in Latin America (LA), has registered dramatic declines in both inequality and poverty since 2000 . The objective of this paper is to explain the drivers behind this.

Looking at the region as a whole, there has been a broad decline in inequality (Cornia, 2012; Azevedo et al. 2013b) and poverty (Vakis et al. 2015) over the 2000s, with the former in contrast to the trend in other regions. This decline has been strongly associated with changes in labor income (Lustig et al. 2014), which in turn may be responding to a decreasing skillspremium in these countries (i.e., a smaller income gap between the less and more educated; Gasparini et al. 2011; Azevedo et al. 2013a.). Other macro trends have also been identified as potential explanatory variables behind the declines in inequality and poverty: sustained economic growth, the commodity boom, conditional transfer schemes, remittances and real exchange rate fluctuations (De La Torre et al. 2014).

Many of the reasons stated above have also impacted Bolivia since 2000. Indeed, growth rates have been significantly above the average in South America, inflation has been under control and current account and fiscal surpluses were the rule rather than an exception until 2014. There has also been political stability since the election of Evo Morales as President in 2006. Finally, Bolivia has one of the highest dependencies on commodity exports in the region.

Overall, our findings suggest that the reduction of inequality and poverty in Bolivia was driven mainly by labor income growth at the lower end of the income distribution. The contribution of non-labor income (rents, transfers, remittances) was important for certain groups but relatively small. Labor income increases were concentrated in the service and manufacturing sectors, and in the informal sector. These changes reduced the skills premium. Pro-poor labor policies have played a role though, both through marked increases in minimum wages in recent years and transfers to specific population groups: school age kids (Bono Juancito Pinto), elderly people (Renta Dignidad) and, pregnant women and newborns (Bono Juana Azurduy). Renta Dignidad in particular has made a big difference for the elderly poor.

Looking ahead, the skills premium could well increase as the spillovers to low skill workers from the commodity boom go into reverse. Given a tighter revenue envelope, it will be essential to ensure that labor and social policies are well designed and targeted.

This paper is organized as follows: Section II describes the evolution of inequality and poverty indicators of Bolivia, and compares them with regional and world aggregates; 
Section III uses aggregate macroeconomic data to contextualize the potential drivers behind changes in inequality and poverty measures; Section IV decomposes poverty and inequality indicators using micro-data; and Section V concludes.

\section{Evolution of Inequality ANd Poverty in Bolivia: A CoMparative Analysis}

A comparison of the Gini coefficient across several groups of countries (expressed below on a scale of $0-1$, where 1 indicates that a single reference unit receives all income and all others receive nothing) demonstrates that inequality is a worldwide phenomenon, but with important differences across regions (Figure 1). Advanced Economies (AEs) generally have lower levels of inequality, especially when looking at the net Gini. ${ }^{2}$ This indicates that AEs generally have more progressive tax systems and/or better transfer mechanisms to the poor. Inequality trends, however, have worsened in AEs (OECD 2011) during the last two decades, while they have generally improved in EMs.

In this context, Bolivia, one of the poorest countries in South America, has dramatically reduced inequality and poverty even compared to peers in Latin-American (LA). In the mid 90s, Bolivia had a Gini coefficient well above the LA average, but it has now reversed. Nonetheless, Bolivia's and LA's net Gini are still higher than those observed in AEs. Importantly, Bolivia's net and market Gini do not differ much, indicating that transfers and other redistributive policies have perhaps played a limited role.

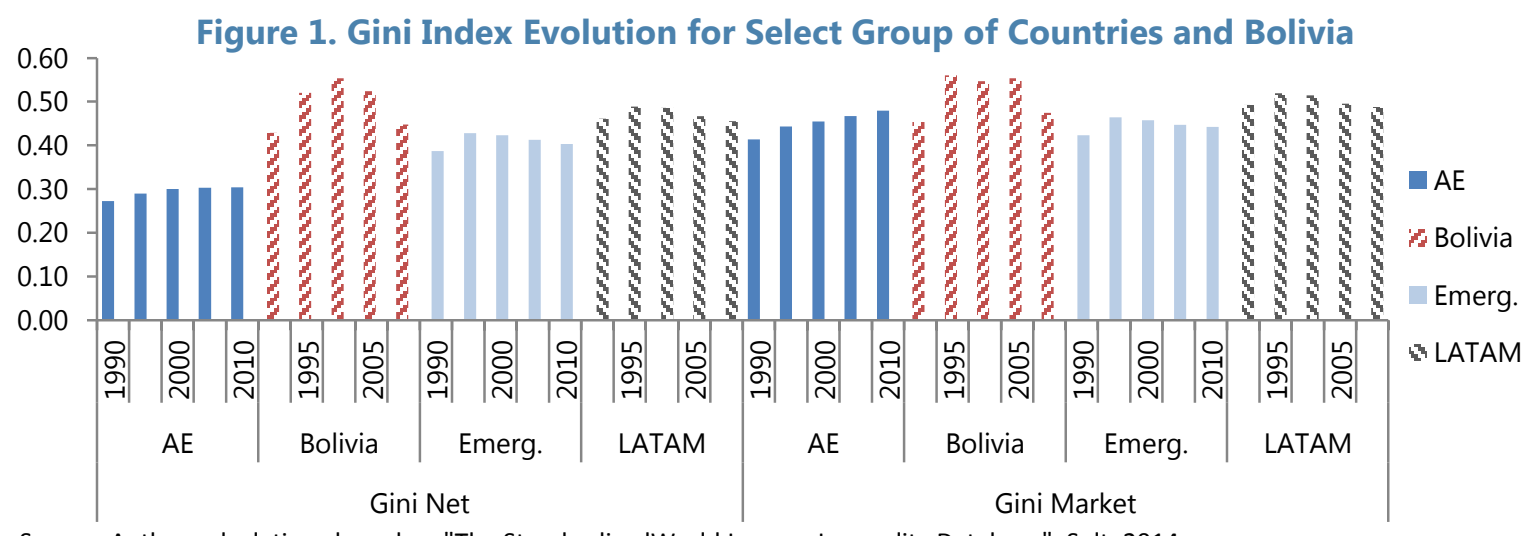

Source: Author calculations based on "The StandardizedWorld Income Inequality Database", Solt, 2014.

Figure 2 illustrates the robustness of Bolivia's inequality decline, using other common measures ${ }^{3}$. Under all the alternative inequality metrics considered, the average annual reduction during 2000-2012 surpassed that observed in other countries of the region. The biggest reduction occurs in the Rate 90/10 indicator, which is the ratio of the income of the 90 th percentile to that of the 10th percentile. As we will discuss later, this does not only

\footnotetext{
${ }^{2}$ This difference between Gini Net and Gini Market (gross) depends on the degree to which taxes are progressive and the extent to which government transfers redistribute income to poorer members of society. For more details see Solt 2009.

${ }^{3}$ The appendix includes detailed definitions of the Atkinson and Theil indices.
} 
reflect that income of the poorest grew faster than income of the richest, but that the richest may have decreased or kept constant their incomes in real terms.

Figure 2. Inequality in LAC: Comparative Inequality Measures
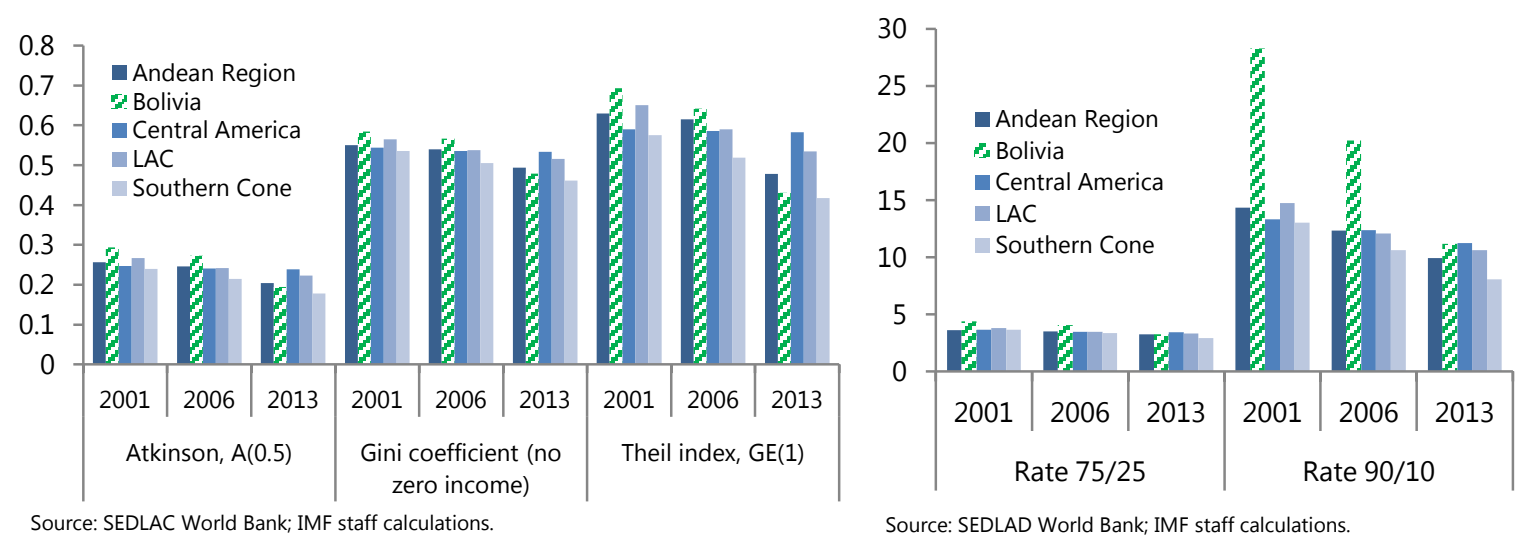

A considerable amount of recent reseach on inequality in LA suggests that a drop in the skills premium might be behind the reduction of inequality in the region. Figure 3 shows a comparison of the change in the gini coefficient between the early 2000s and early 2010s, calculated for Bolivia and 4 other countries with similar characteristics (small open economies that are mainly commodity exporters). The chart suggests that economic growth is not a sufficient condition to generate a reduction in inequality; indeed Bolivia, Peru, Paraguay, and Ecuador experienced very similar annualized growth rates during the period, but their performance in reducing inequality was very different. For example, Peru had the highest economic growth, but inequality barely fell.

A closer analysis of Figure 3 confirms that a reduction in the wage gap (defined as the ratio of wages of the highly-educated to lowly-educated) is associated with a reduction in gini coefficient, but with some important nuances. Bolivia reduced strongly inequality within high skilled workers, and moderately in the low and mid-skill workers groups (see blue bars); meanwhile Ecuador reduced its gini coefficient in a more even way between the subgroups of workers by education level. 
Figure 3. Growth, Changes in Gini Coefficient (by educational level) and Wage Gap between early 2000 s and 2010 s

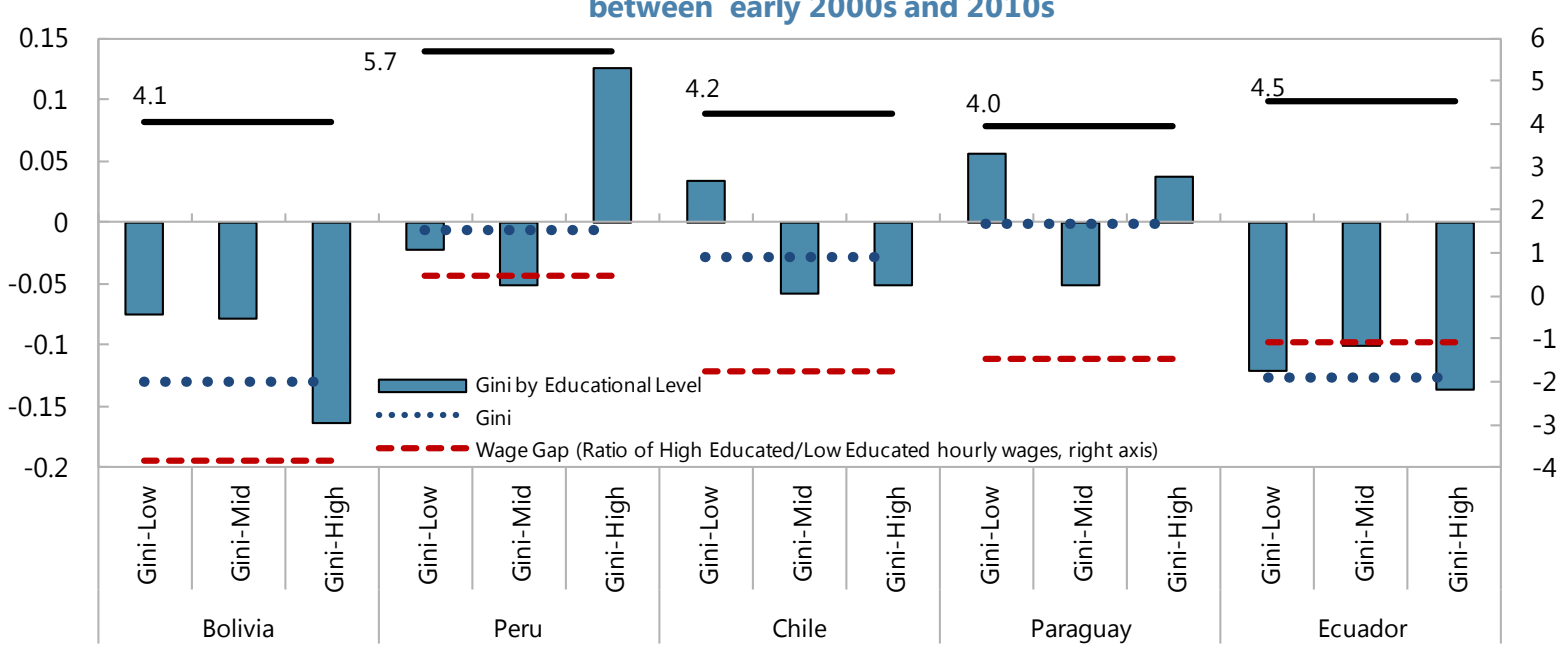

With regards to poverty, Asian countries have registered the fastest declines in poverty rates during the last three decades (see Figures 4 and 5). Poverty levels in LA have been much lower than in Asia or Africa, and levels have declined somewhat during recent decades. This has helped reduced the share of the population living with less than \$USPP-2005 1.25 daily from 12.5 percent in 1987 to 4.6 percent in 2011, and the share of population living with less than \$USPP-2005 2.5 daily from 30.3 to 13.2 percent. Bolivia reduced the number of poor people in a material way as well. The share of people living under the $\$ 1.25 /$ day poverty line dropped from 17 percent in 1996 to 7 in 2011; and from 33.7 to 16.2 percent when using the $\$ 2.5 /$ day poverty line.
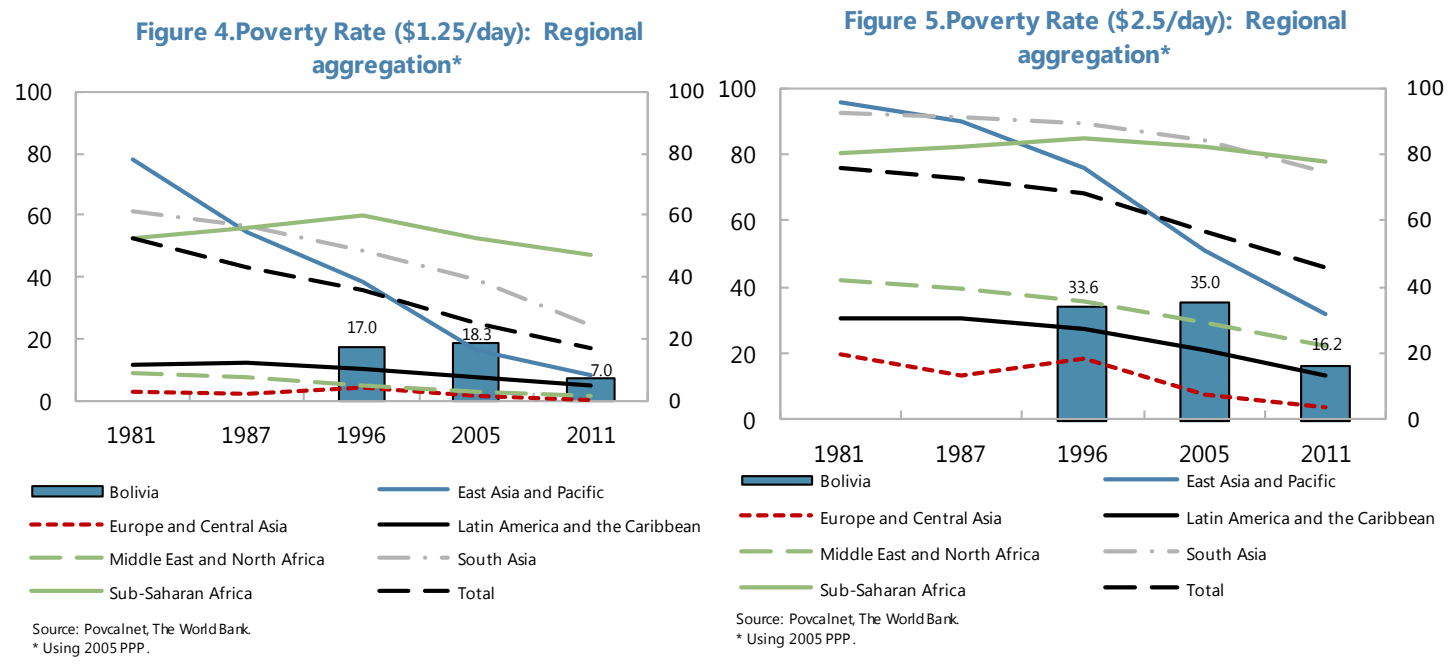


\section{Potential Effects of Macro Trends and Public Policy}

In this section, we look at some macro aggregates and specific public policies that could be potential determinants of the reduction of inequality and poverty in the region. And most of them apply to Bolivia: sustained economic growth, favorable terms of trade, conditional transfer schemes, remittances and exchange rate fluctuations (De La Torre et al. 2014).

\section{a) Economic Growth}

In general, it is accepted that growth should lead to a reduction in poverty but that the impact on inequality is ambiguous (e.g., Ravallion, 2001 and Bourguignon, 2004). Bolivia has sustained high economic growth during the past 15 years, with an average growth rate of real GDP of 4.2 percent, 1 percent point above for LAC. Much of this is attributable to high international prices of its main export products, which grew 800 percent in nominal US\$ dollar terms. Bolivia is now more dependent on exports than it was 15 or 25 years ago (Bolivia's exports were 23 percent of GDP in 1990, 18 percent in 2000, 41 percent in 2010, and had a peak of 47 percent in 2012), and its exports are more concentrated in a reduced set of commodity goods, mainly minerals and hydrocarbons. Overall, Bolivia's real GDP grew slightly more than 80 percent during 2000-2014, and 42 percent in real per capita PPP terms.

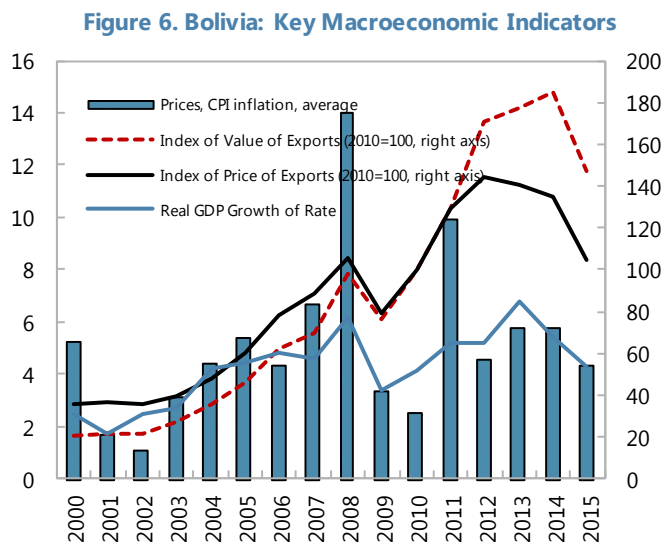

Source: IMF Staff calculations based on WEO

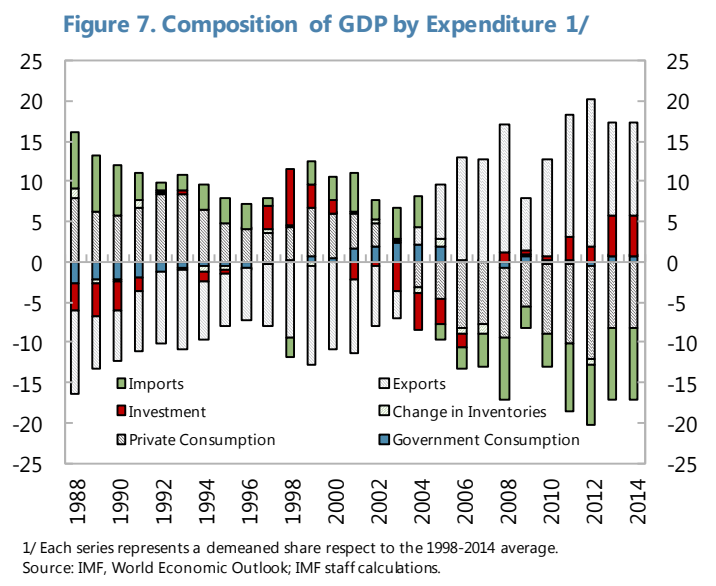

An important part of the growth story has been public investment. Total investment grew by 100 percent between 2000 and 2013, and the share of public investment as percent of total investment increased from 30 percent to 56 percent during the same period. This may have contributed to a stronger impact of growth on inequality and poverty, for example via investment in infrastructure (roads, electricity supply, and sanitation) as suggested by Datt and Ravallion (2002) and Fan et al. (1999). 


\section{b) Exchange Rate Policy}

Bolivia has followed a de jure crawling peg exchange rate regime during the sample period, with sustained nominal depreciations between 2000 and 2005, and nominal appreciations between 2006 and 2011. During the last 4 years, however, it has maintained a de facto US\$ peg, which has helped further de-dollarization of the economy and maintain price stability. Importantly, the real effective exchange rate has appreciated strongly during the last couple of years and this can have a varying impact on inequality and poverty depending on the structure of the economy. On the one hand, it could discourage employment in export-oriented firms, thus increasing levels of poverty and inequality. On the other hand, lower import prices might reduce inflationary pressures and, depending on the composition of consumption, favor more vulnerable groups. The import sector could also benefit from higher economic activity. As we will see in the next sections, in the case of Bolivia, a key channel has been the impact of a strong currency on the service sector (e.g., commerce). Bolivia's trade structure suggests that a real depreciation of the currency would favor at most to 20 percent of exports (those concentrated in nontraditional products), and would negatively affect imports which is intensive in labor; these elements may support a positive effect of the recent real appreciation on the reduction of inequality and poverty.

\section{c) Remittances}

Bolivia benefited from a positive shock to financial inflows in the form of remittances. During the first half of the period between 2000 and 2014, remittances showed a clear upward trend; in 2007, they were almost 8 percent of GDP. This trend stabilized in U.S. dollar terms after 2008, and reversed as a percent of GDP, representing around $3 \frac{1}{2}$ percent of GDP in 2014. This declining path is mainly linked to lingering effects of the financial crisis which affected salaries of Bolivian immigrants

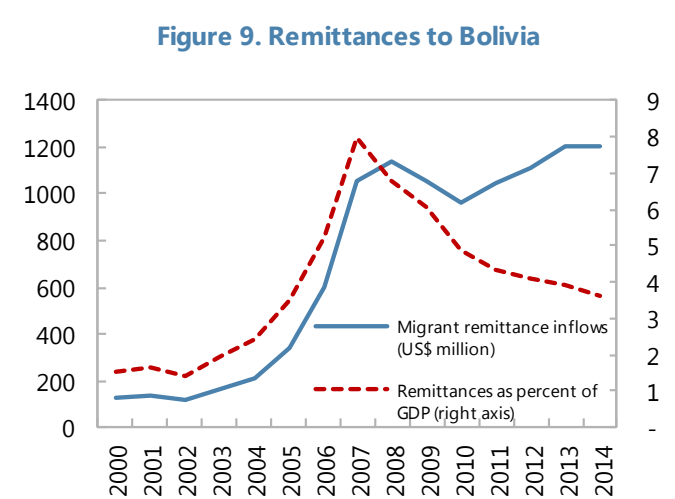

Source: World Bank and IMF World Economic Outlook; IMF staff calculations. in Spain and United States, and a lower growth rate in Argentina; and lower levels of immigration given the relatively favorable economic conditions in Bolivia.

Active social and economic policies were also key in the process of redistributing wealth. Indeed they likely affected both labor and non-labor income, and include: i) material 
increases of the minimum wage and capped maximum salaries in the public sector from 2006 onwards; ${ }^{4}$ and ii) implementation of unconditional and conditional transfers to vulnerable sectors (elderly people, primary school kids, and pregnant women and newborns). Below, we elaborate on these in more detail.

\section{d) Salaries}

The minimum wage in Bolivia grew by 122 percent in real terms from 2000 to 2015, mostly due to an explicit catch-up policy that has been more vigorous since 2011 - the change during 2010-2015 accounts for $100 \mathrm{pp}$. of the overall increase. However, despite all these efforts, Bolivia still has the lowest minimum wage in South America (US\$240 per month). An important caveat looking at the impact of the minimum wage is to look at coverage. In the case of Bolivia, it directly affects only workers in the formal sector, which represent about $1 / 4$ of the workforce. ${ }^{5}$ However, there could be a lighthouse effect to the informal sector, in which case a hike in the minimum wage may provide a higher reference salary in the informal sector. ${ }^{6}$
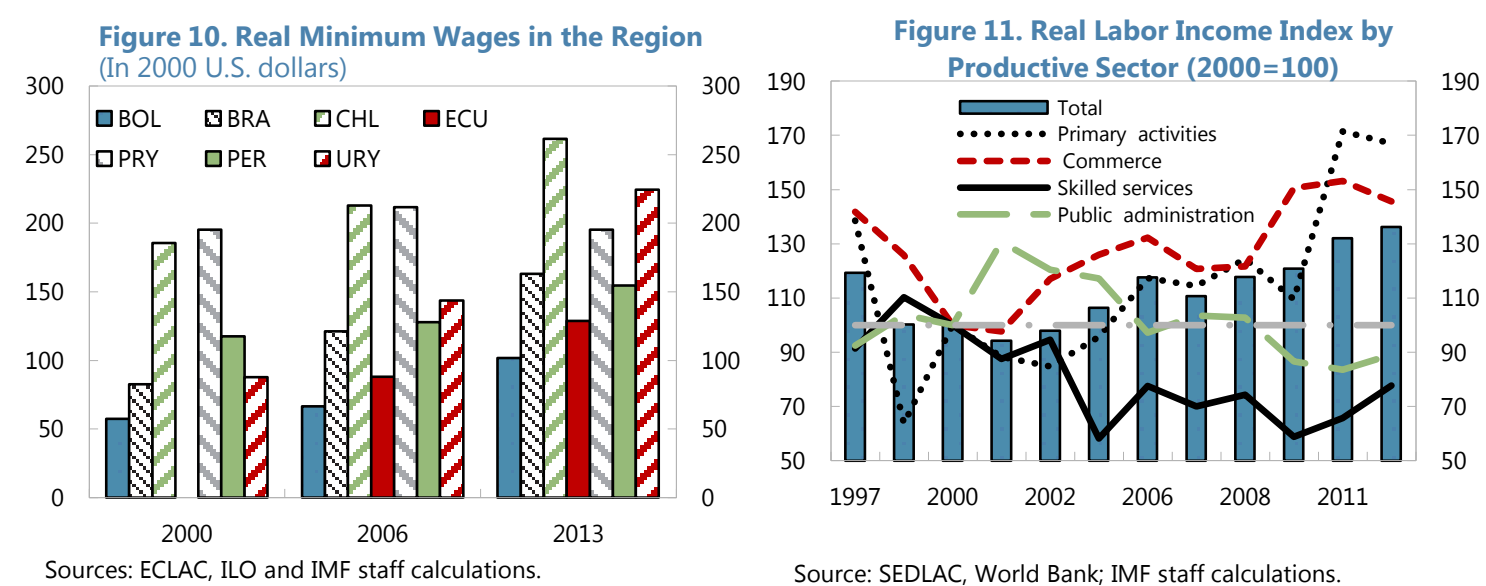

Source: SEDLAC, World Bank; IMF staff calculations.

A broader indicator of income earned by workers is labor income derived from Household Survey data. Figure 11 shows the evolution of real labor income by productive sector. Average labor income increased by 36 percent from 2000-2013, but not all sectors benefitted equally. Primary activities, commerce and construction saw large salaries increases, whereas public administration and skilled services workers (defined as those

\footnotetext{
${ }^{4}$ Indeed, maximum salaries in the public sector were capped from 2006 to 2012. Salary adjustments took place within this period, although mainly affected workers in the lower end of the wage distribution.

${ }^{5}$ It is worth noting that the share of workers in the informal sector declined from 85 percent in 2001 to 75 percent in 2013, according to the legal definition of informality (share of labor force not covered by a pension scheme).

${ }^{6}$ For evidence of the lighthouse effect, see Maloney et al. (2001), Boeri et al. (2010) and Khamis (2008).
} 
with tertiary education) experienced real income declines. This may have helped to reduce inequality indicators since salaries in the former group of workers are lower than those in the latter.

\section{e) Transfers}

The Bolivian government introduced three major transfers in 2006 and has progressively expanded them. More specifically, one unconditional and two conditional cash transfers (CCT) make up most of government expenditure on redistributive policies. ${ }^{7}$ The unconditional one is Renta Dignidad, which is a monthly non-contributory social security program for all people above 60 years. It was created in 2008 as a successor to an earlier transfer implemented in 1994 (Bono Solidario). The amount of this transfer was flat until 2012. It was increased Figure 12. Bolivia: Renta Dignidad 1/ by 25 percent in 2013 and in 2014 a

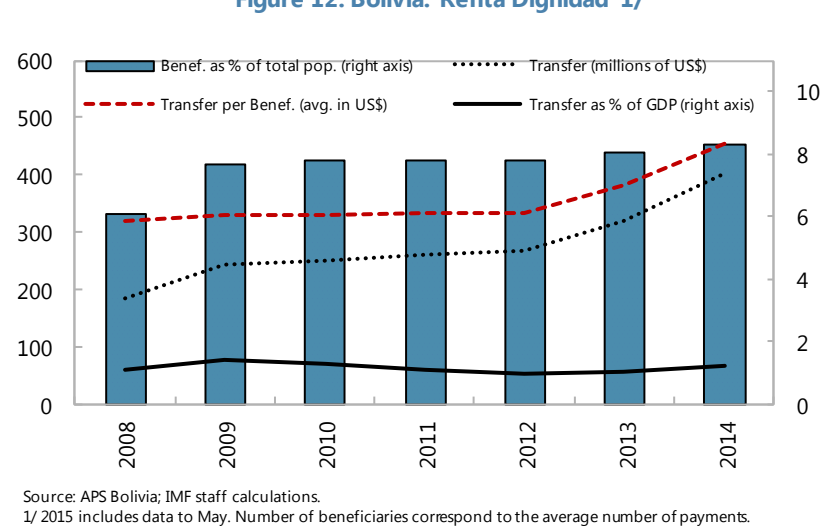
$13^{\text {th }}$ month payment was added (Christmas bonus "Aguinaldo") ${ }^{8}$. One CCT is Bono Juancito Pinto, which was implemented in 2006 as a cash transfer for families with kids in primary school ( $1^{\text {st }}$ to $6^{\text {th }}$ grades $)$, and extended progressively to cover all secondary school students by 2014. This transfer is paid at the end of each year, after students satisfy the condition of not dropping out of school during the corresponding year. The second CCT is Bono Juana Azurduy, for expectant and new mothers and their infants. It was started in 2009.

\footnotetext{
${ }^{7}$ For interesting case studies of other CCTs in Latin America see Bosch and Guajardo (2012), Celhay et al. (2015), Garriga (2014) and Gertler et al. (2014).

${ }^{8}$ Currently, the monthly payment of the Renta Dignidad is Bs.250 (US\$35.9) for persons not receiving contributory pensions, and Bs. 200 (28.7) for recipients of contributory pensions.
} 
Figure 13. Bolivia: Bono Juancito Pinto

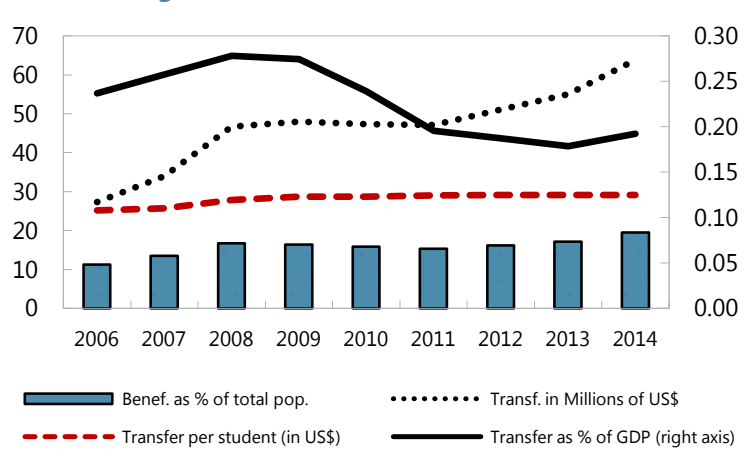

Source: MEFP Bolivia; IMF staff calculations.
Figure 14. Bolivia: Bono Juana Azurduy 1/

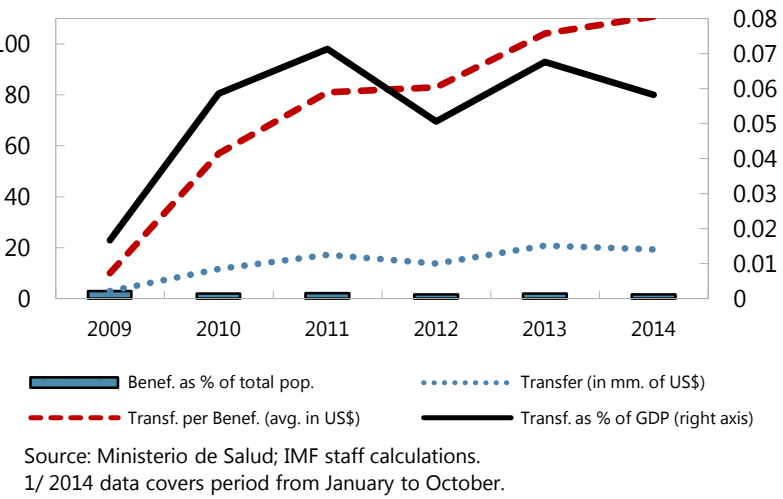

Bono Juancito Pinto has the largest population of beneficiaries (Figures 12-14), although it is not as important in terms of spending (close to 0.2 percent of GDP), and per capita income (around US\$30 dollars a year). On the other hand, expenditure on Renta Dignidad is larger than one percent of GDP - the biggest transfer - and its number of beneficiaries is above 8 percent of total population. Finally, Bono Juana Azurduy is the least important in terms of spending (0.06 percent of GDP per year in 2014) and beneficiaries (1.6 percent of total population). Overall, this suggests that Renta Dignidad might be more effective in increasing income for particular groups of people. There is no doubt, however, that Bono Juancito Pinto and Bono Juana Azurduy are important initiatives to improve health and education, which ultimately should reduce poverty and inequality.

\section{EXPlaining Inequality AND POVERTy From Micro DATa}

\section{A. Comparing Official and SEDLAC Data}

Figure 15. Bolivia: Inequality Measures

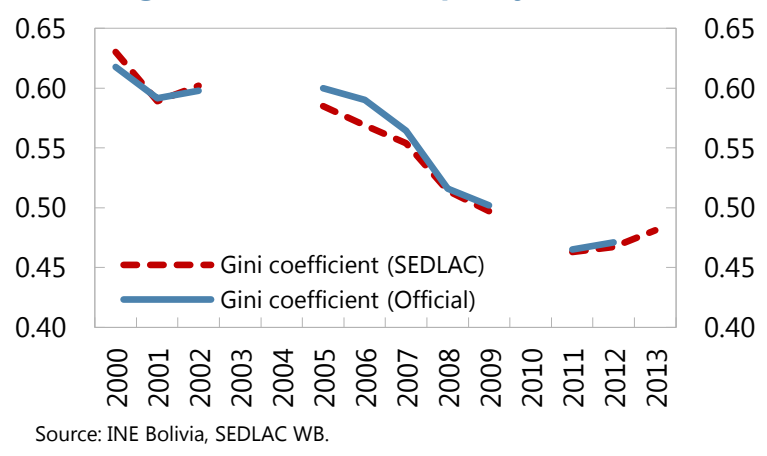

Household Surveys provide a comprehensive source of household income measures, and so are the primary source to construct inequality and poverty indicators. However, there is not a unique convention to define or adjust income definitions or to assure consistency across time and between countries. The Socio-Economic Database for Latin America and the Caribbean project (SEDLAC, World Bank) represents a big effort to standardize and harmonize household surveys between countries and across time in LA countries. As a robustness check, in Figures 15-17 we show two common inequality measures and an alternative set of definitions of poverty using official estimates and SEDLAC data. The 
comparison suggests that discrepancies in definition imply only marginal differences and do not affect the trend or magnitude of the inequality and poverty reduction in Bolivia. ${ }^{9}$

As shown in Figure 15, the gini coefficient dropped steadily during the 14 years between 2000 and 2013, but more rapidly during 2007-11. Estimates of poverty show similar trends, with a constant reduction in the number of poor people during most years, with accelerated progress during 2007-11 (Figures 16-17). The major reductions occurred in rural areas, where according to official estimates, extreme poverty decreased from 75 to 41 percent, and moderate poverty fell from 87 to 61 percent between 2000-2012 (Table A1 in the appendix).
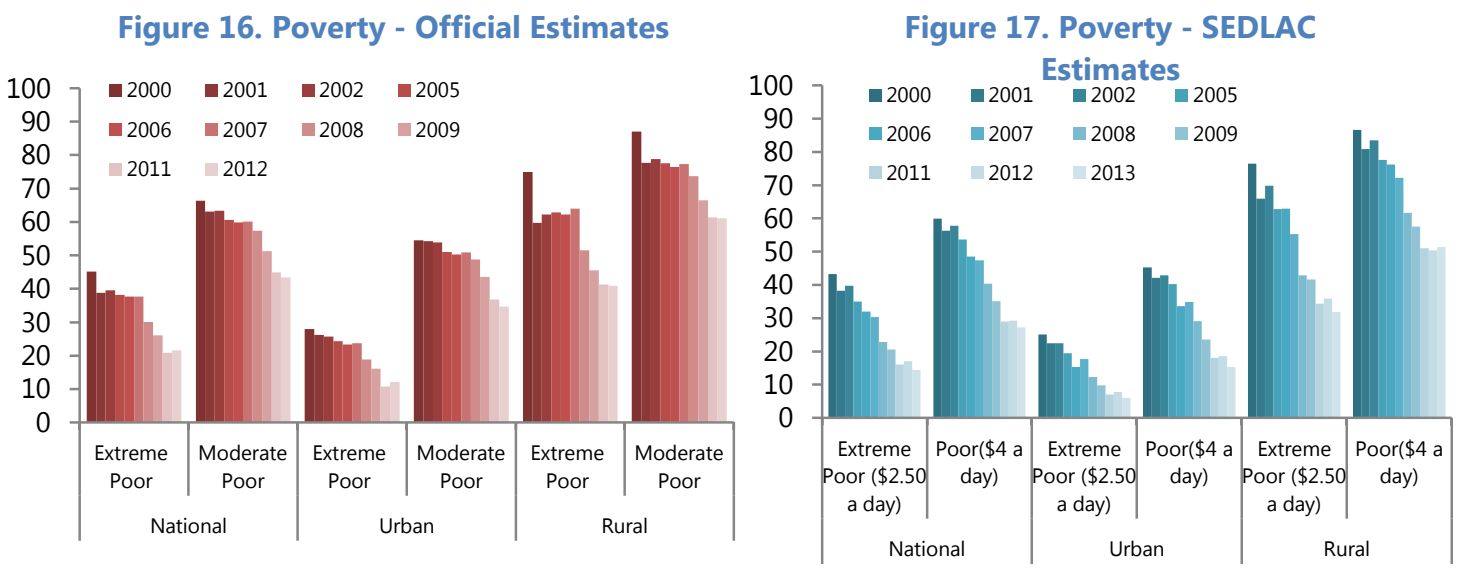

\section{B. Who Gained the Most?}

A natural question is what elements drove the reduction in poverty and inequality? Or, alternatively, who gained more during this period? A comparison of the income distribution (Figure 18) shows the monthly household income per capita for each of the 100 percentiles of the survey sample. First, it illustrates that income of households grew significantly through the years, likely reflecting greater economic activity. Second, the role of non-labor income (which includes rents, transfers, and other non work-related earnings) is limited since it represents at most around 20 percent of total income (Table 1), although government transfers to households have doubled since 2006 as a share of income. Third, the average household income per capita of the top 15 percent of the population increased just slightly between 2001 and 2006 and was flat during 2006-2013.

\footnotetext{
${ }^{9}$ In both official and SEDLAC databases, reported income is net of taxes. Regarding adjustments made to consider equivalence scales in income variables, SEDLAC poverty estimates are computed using household per capita income. Inequality indicators are computed for both household per capita income and for an adjusted household income variable. In this section we report the former.
} 
Figure 18. Bolivia: Income Distribution for Selected Years (in Real Bs.) ${ }^{1 /}$

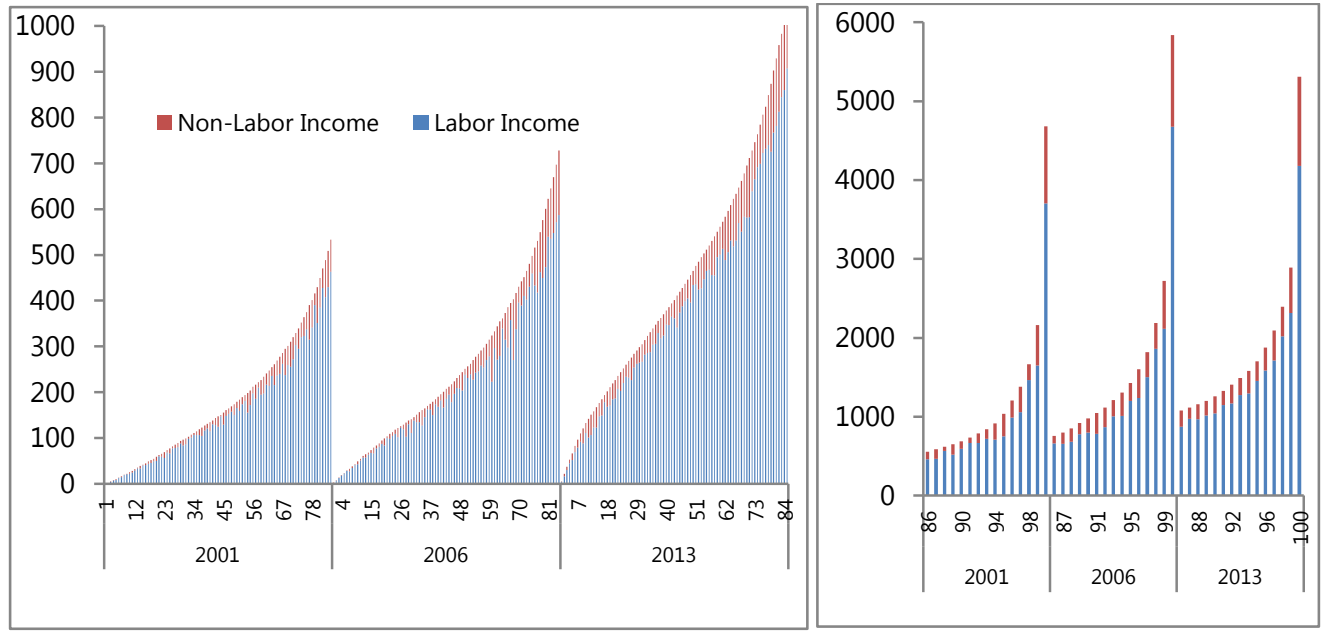

$1 /$ The distributions show the monthly household income per capita in real terms (base year=2000). Left chart: $1^{\text {st }}$ to $85^{\text {th }}$ percentile; right chart: $86^{\text {th }}$ to $100^{\text {th }}$ percentile.

Source: INE Bolivia, IMF staff calculations.

Table 1. Composition of the Household Total Income per Capita (Selected Years)

\begin{tabular}{lccccccc} 
& $\mathbf{2 0 0 1}$ & $\mathbf{2 0 0 2}$ & $\mathbf{2 0 0 6}$ & $\mathbf{2 0 0 7}$ & $\mathbf{2 0 1 1}$ & $\mathbf{2 0 1 2}$ & $\mathbf{2 0 1 3}$ \\
\hline Labor & 83.6 & 84.7 & 82.8 & 82.4 & 81.8 & 80.9 & 79.1 \\
Non - labor & 15.6 & 14.5 & 16.4 & 17.0 & 17.9 & 18.4 & 20.4 \\
$\quad$ Returns of Capital & 0.2 & 0.3 & 0.2 & 0.1 & 0.2 & 0.1 & \\
$\quad$ Transfers from Government & 5.9 & 5.4 & 5.7 & 5.4 & 9.8 & 11.2 & \\
$\quad$ Transfers between households & 9.4 & 8.8 & 10.5 & 11.5 & 7.8 & 7.1 & \\
\hline
\end{tabular}

\section{Impact of Renta Dignidad}

While non-labor income is on average a small part of total income, changes in it are still important for particular age groups. For example, non-labor income has increased its share of total income from about 15 percent in 2001 to almost 50 percent of total income in 2013 for the $75^{\text {th }}$ percentile of people above the age of 60 (see Table 2). Regarding the impact of Renta Dignidad, ${ }^{10}$ Figure 19 and Table 2 suggest that it has likely played an important role for elderly people (notwithstanding that much of the increase in non-labor income was due to other reasons). Moreover, its contribution is important for not just the poorest: Renta Dignidad represents the 24 percent of total income for the $25^{\text {th }}$ percentile, 15 percent for 50th percentile and around 10 percent for 75 th percentile among elderly people. ${ }^{11}$

\footnotetext{
${ }^{10}$ In 2013, Renta Dignidad distributed up to 250 monthly Bs. per person to all elderly people of $60>$ years old and was implemented in 2008.

${ }^{11}$ For a broad study of the impact of Renta Dignidad, see UDAPE (2013). This publication finds that Renta Dignidad reduced the poverty incidence in a range of 13.5 to 16.1 percent (according to the poverty line threshold) in the target population.
} 
Figure 19. Share of Labor and Non-Labor Income

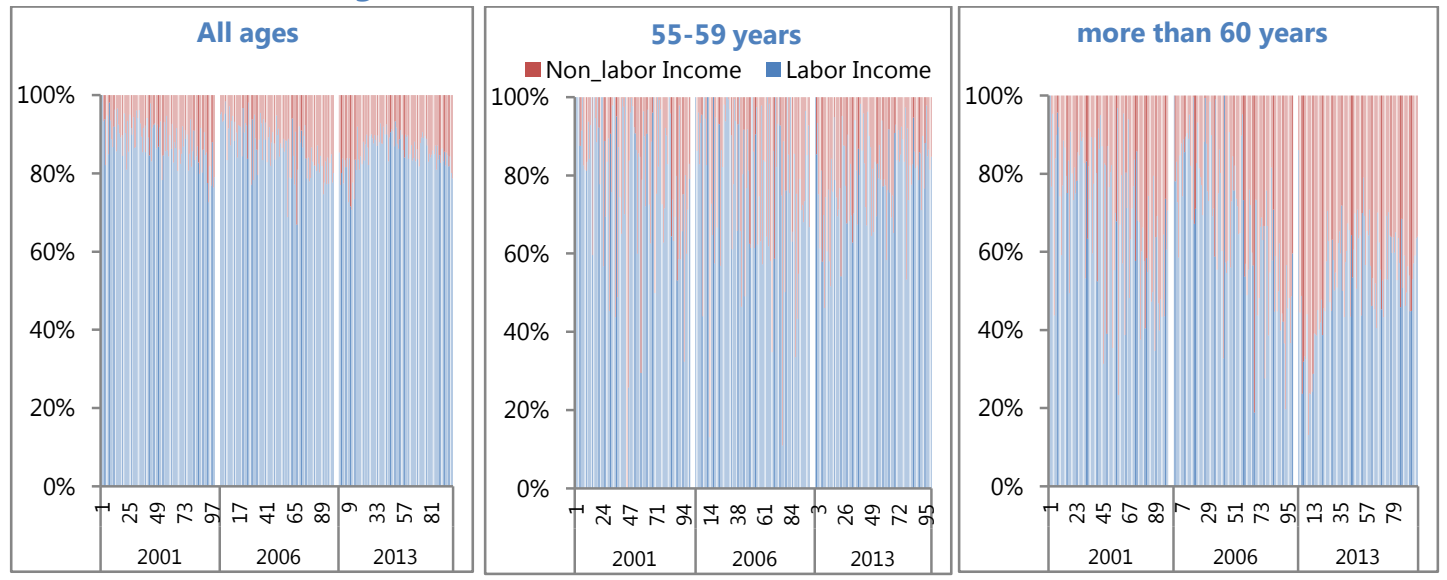

$1 /$ The distributions show the shares of monthly household income per capita in real terms (base year=2000). Source: INE Bolivia, IMF staff calculations.

Table 2. Potential Effects of Renta Dignidad (Monthly Household Income per Capita in Real Bs.)

\begin{tabular}{|c|c|c|c|c|c|c|c|c|}
\hline \multirow[b]{2}{*}{ Household } & \multirow[b]{2}{*}{ Percentile } & \multicolumn{2}{|c|}{2001} & \multicolumn{2}{|c|}{2006} & \multicolumn{3}{|c|}{2013} \\
\hline & & Labor Income & $\begin{array}{l}\text { Non Labor } \\
\text { income }\end{array}$ & Labor Income & $\begin{array}{l}\text { Non Labor } \\
\text { income }\end{array}$ & Labor Income & $\begin{array}{l}\text { Non Labor } \\
\text { income }\end{array}$ & $\begin{array}{c}\text { Non Labor Income: } \\
\text { Renta Dignidad } \\
\text { (percent of total } \\
\text { income) }\end{array}$ \\
\hline \multirow{3}{*}{ All Population } & $\mathrm{P} 25$ & 66 & 11 & 102 & 20 & 234 & 26 & $3.8 \%$ \\
\hline & P50 & 166 & 14 & 239 & 13 & 434 & 31 & $2.2 \%$ \\
\hline & P75 & 323 & 41 & 459 & 38 & 699 & 86 & $1.2 \%$ \\
\hline \multirow{3}{*}{$\begin{array}{l}\text { Households with at } \\
\text { least one member } \\
\text { aged } 60+\text { years }\end{array}$} & $\mathrm{P} 25$ & 66 & 11 & 84 & 37 & 183 & 77 & $24.4 \%$ \\
\hline & P50 & 156 & 23 & 177 & 66 & 329 & 136 & $15.4 \%$ \\
\hline & P75 & 303 & 51 & 329 & 150 & 416 & 370 & $9.2 \%$ \\
\hline
\end{tabular}

Source: INE Bolivia, IMF staff calculations.

\section{Disaggregated Real Income Data}

Figures 20 and 21 illustrate several breakdowns for the indices (base year 2001=100) of real labor and non-labor income per capita, ${ }^{12}$ respectively, taking into account: age, gender, rural/urban, geographical zone (departments), informal/formal status, education and activity sector. Both sets of charts show the mean of labor income and non-labor income for three reference years: 2001, 2006, and 2013. The size of the bubbles represents the relative size of each sector/group in the population for each given year.

\footnotetext{
${ }^{12}$ In the charts, labor income per capita excludes observations where income is equal to zero, while non-labor income per capita includes observations where income is equal to zero. The latter is to allow for a proper comparison of mean incomes before and after the introduction of the CCTs, especially Renta Dignidad.
} 
Key stylized facts are: i) labor income of skilled people decreased in real terms between 2001 and 2013, ${ }^{13}$ especially in the formal sector; ii) labor income increased for most low-skilled workers, mainly in the informal sector; iii) labor income increased in all urban areas, but the increases were more limited in the Departments of La Paz and Cochabamba; (iv) in rural areas, workers in Oruro, Potosi and Santa Cruz saw important gains; (v) the youngest (1525 years), and the older workers (51-60 years) experienced the most rapid increases in labor income; and (vi) manufacturing and services sectors gained most, although increases were concentrated in the informal sector.

Table 3. Growth Rate of the Number of People Earning a Greater than Zero Non-Labor Income

\begin{tabular}{|c|c|c|c|}
\hline & 2001-2006 & 2006-2013 & 2001-2013 \\
\hline 0-14 years & $14 \%$ & $330 \%$ & $392 \%$ \\
\hline 15-20 years & $6 \%$ & $4 \%$ & $11 \%$ \\
\hline 21-25 years & $-10 \%$ & $34 \%$ & $21 \%$ \\
\hline 26-30 years & $-12 \%$ & $34 \%$ & $18 \%$ \\
\hline 31-35 years & $35 \%$ & $33 \%$ & $80 \%$ \\
\hline 36-40 years & $43 \%$ & $26 \%$ & $81 \%$ \\
\hline 41-45 years & $7 \%$ & $7 \%$ & $14 \%$ \\
\hline $46-50$ years & $8 \%$ & $29 \%$ & $40 \%$ \\
\hline 51-55 years & $52 \%$ & $17 \%$ & $78 \%$ \\
\hline 56-60 years & $43 \%$ & $84 \%$ & $163 \%$ \\
\hline+60 years & $33 \%$ & $264 \%$ & $385 \%$ \\
\hline
\end{tabular}

Regarding real non-labor income per capita, it increased in rural and urban areas, although more strongly in the former which likely helps the greater poverty reduction. The youngest and oldest people of the distribution received more non-labor income in 2013 than in 2001, which could be related with the three cash transfers implemented after 2006. It is worth noting that the number of people receiving a positive non-labor income increased by 150 percent between 2001 and 2013, compared to a 50 percent increase in the number of people earning labor income during the same period (Table 3). ${ }^{14}$

\footnotetext{
${ }^{13}$ Unskilled (Never attended school or Incomplete Primary Education); Low skilled (Complete Primary or Incomplete Secondary Education); Skilled (Complete Secondary, Incomplete Tertiary or Complete Tertiary Education).

${ }^{14}$ Interestingly, most of the increase occurred during 2006-2013, likely reflecting a larger share of population reached by redistributive policies.
} 
Figure 20. Bolivia: Indices of Real Labor Income per Capita

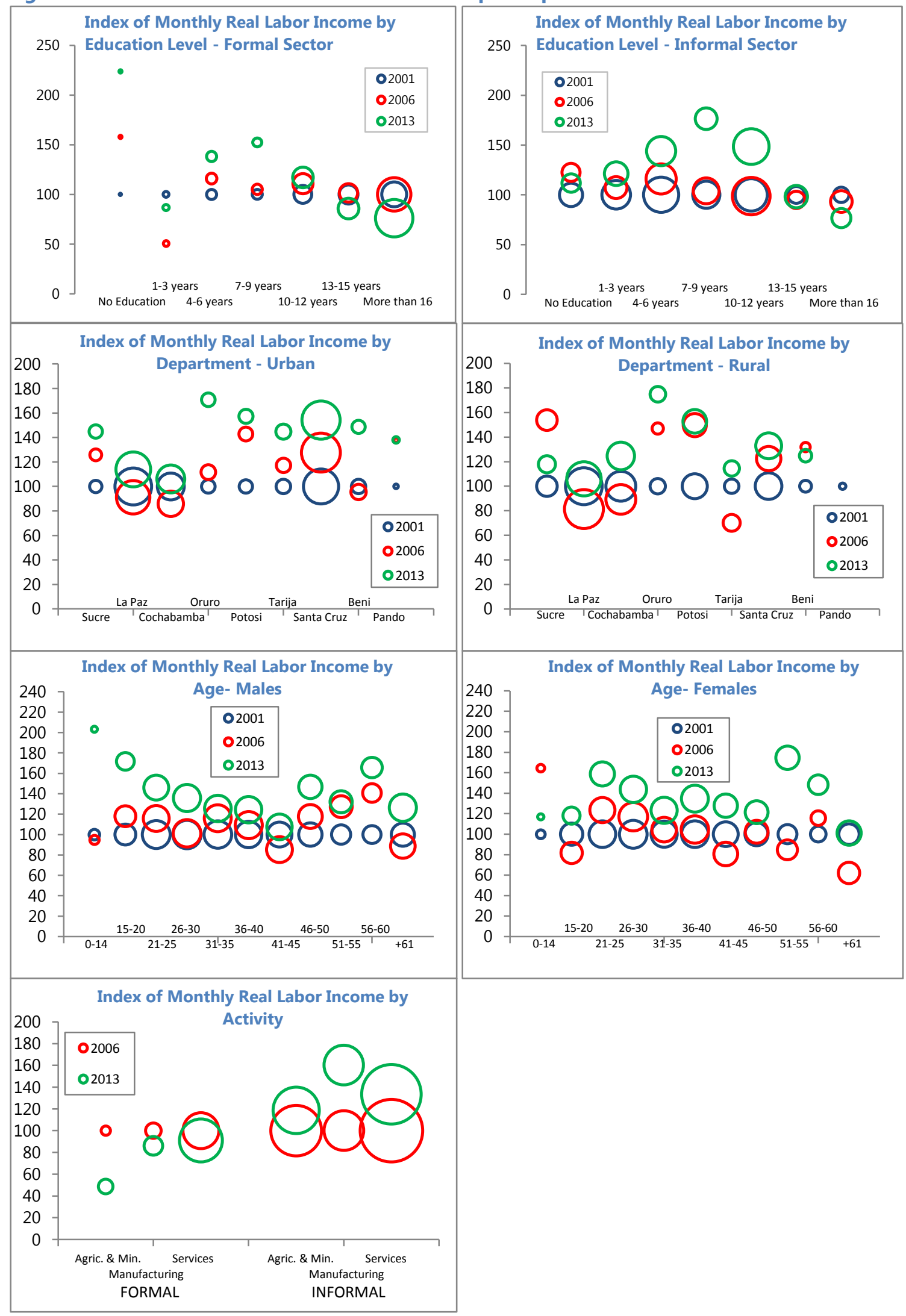


Figure 21. Bolivia: Indices of Real Non-Labor Income per Capita

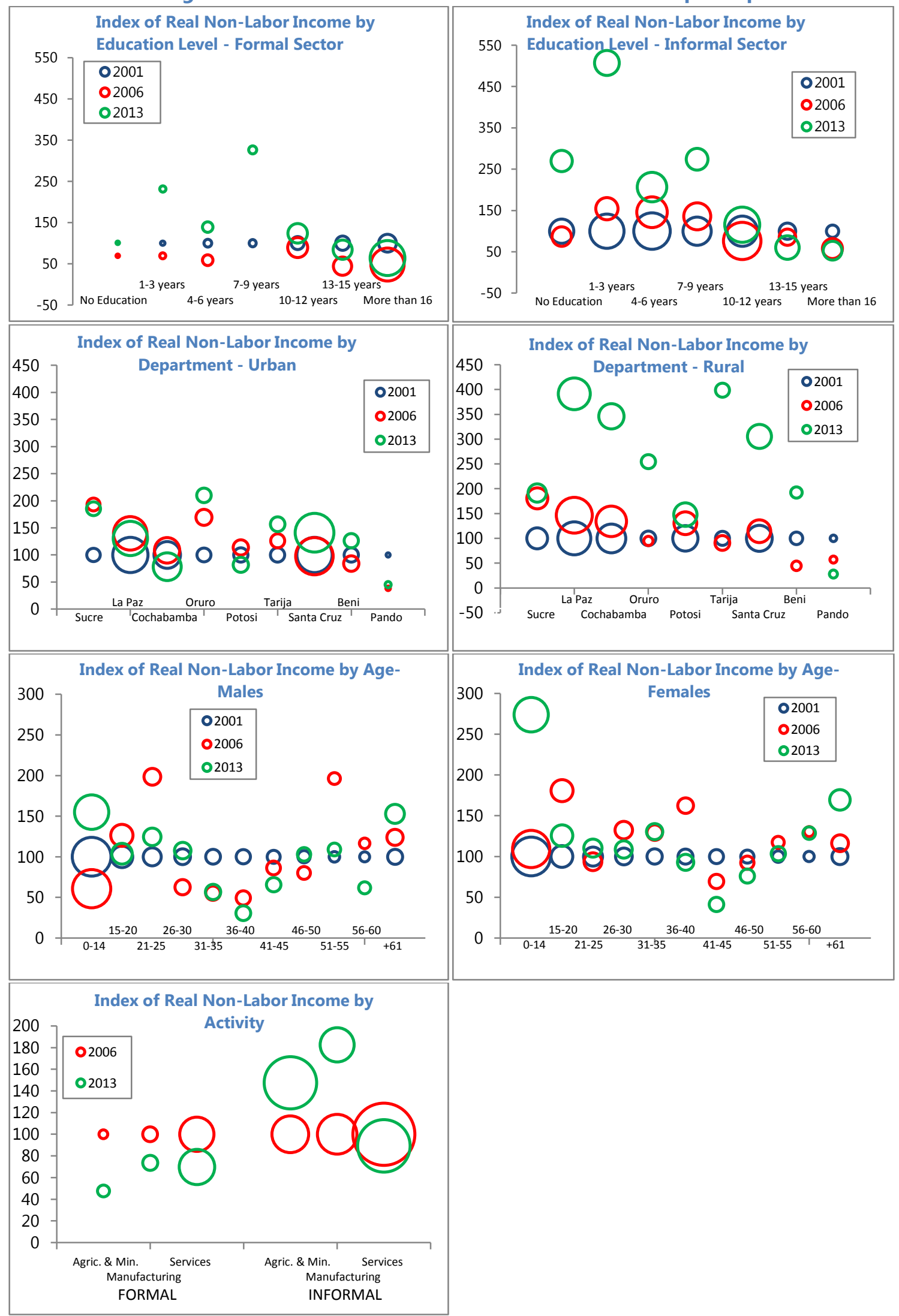




\section{Inequality and Poverty Decompositions}

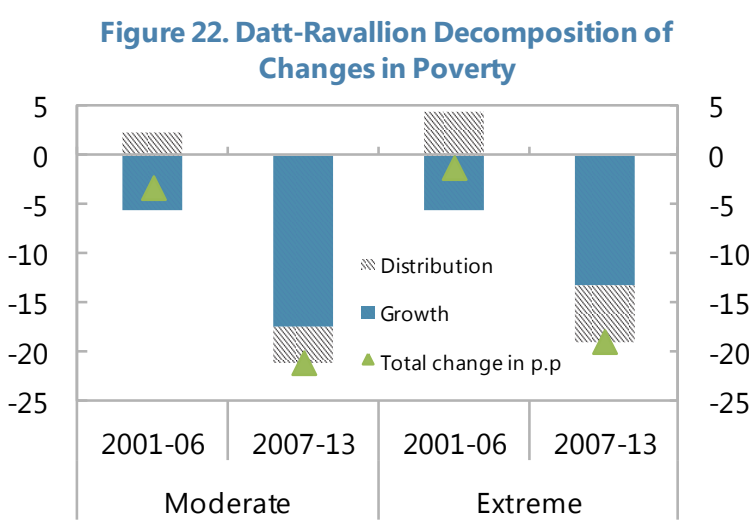

Source: IMF staff calculations based on INE Bolivia data.
So far, we have a better understanding of the dynamics of total income, the natural next question is which elements contributed most to the decline in inequality and poverty? In this subsection, we rely on a set of Shapley decompositions. The first is the DattRavallion (Datt and Ravallion, 1992) decomposition (Figure 22) which decomposes changes in poverty rates. Results suggest that overall growth of total income drove the reduction in poverty more than changes in the distribution (changes in

inequality). ${ }^{15}$ Indeed, 83 (70) percent of the large reduction in moderate (extreme) poverty is explained by growth between 2007 and 2013, and changes in the distribution (inequality) actually increased poverty levels between 2001 and 2006.

A similar analysis is used for inequality and poverty indicators by income source. For this, we calculate a Shapley decomposition of the change in select poverty (moderate and extreme, according to national poverty lines) and inequality (gini coefficient) measures using the method proposed in Azevedo et al. (2013). They proposed a Shapley-Shorrocks decomposition that corrects path dependence in the standard Barros et al. (2006) calculation. ${ }^{16}$ The method is simple; first, it divides real household income per capita into $j$ components (e.g. household income per capita $=$ household non-labor income per capita + household labor income per capita in the formal sector + household labor income per capita in the informal sector) and chooses two years to compare a poverty or inequality indicator.

$$
Y_{H p c}=Y_{H p c, 1}+Y_{H p c, 2}+\cdots+Y_{H p c, j}
$$

Selected inequality and poverty indicators are constructed based on $Y_{H p c}$. Let $\vartheta$ be any measure of inequality or poverty, and $F(\quad$ ) be the cumulative density function of household income per capita:

$$
\vartheta=\varnothing\left(F\left(Y_{H p c, 1}, Y_{H p c, 2}, \ldots, Y_{H p c, j}\right)\right)
$$

\footnotetext{
${ }^{15}$ The redistribution component is insensitive to changes in the distribution above the poverty line. See Datt and Ravallion (1992).

${ }^{16}$ There are some important methodological issues and associated caveats to note when using Shapley decompositions (see Sastre and Trannoy, 2002).
} 
Then, the method essentially alters the distribution of total household income per capita in the latter year by replacing every component of the distribution by data from the same component in the former year in any possible order. After that, a counterfactual inequality/poverty indicator is calculated with that new distribution to obtain:

$$
\tilde{\vartheta}=\emptyset\left(F\left(Y_{H p c, 1}, Y_{H p c, 2}, \ldots, \widetilde{Y_{H p c, J}}\right)\right)
$$

Since the order in which the cumulative effects are calculated matters, the process repeats for each possible path. Finally, the average effect of each component represents the contribution of it to the change in the select indicator.

The results of the Shapley-Shorrocks decompositions are shown in Figures 23-25. We focus our analysis on the period 2007-2013 given this was the time of the most rapid inequality and poverty reduction.

First, looking at differences in educational level (Figure 23), changes in the distribution of skilled and low-skilled workers were the main determinants explaining the decrease in poverty and inequality indicators between 2007-2013. Between 2007-2013, skilled workers experienced a reduction in their real salaries (reducing inequality), but at the same time stayed well above poverty lines.

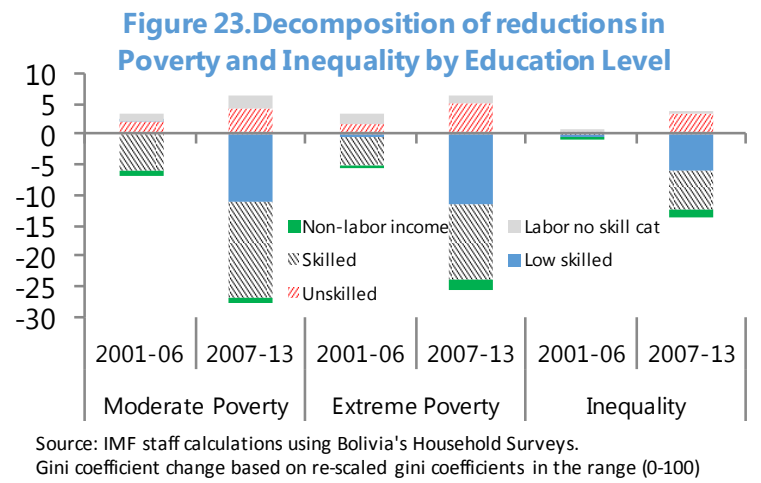
Low-skilled workers increased their salaries mainly in the informal sector (reducing inequality and poverty). It is worth noting that most of the workforce in the formal sector is concentrated in the skilled-workers category, while low-skilled workers are the main part of the informal sector. The contribution of non-labor income to reducing inequality and poverty was relatively minor but positive.

Second, with regard to formal/informal status, Figure 24 illustrates that the reduction of inequality and poverty was mainly driven by changes in the distribution of formal workers rather than changes in the distribution of informal workers. The interpretation of this result is not straightforward. First, formal high-skilled workers experienced a decrease in their real labor income, however formal low-skilled salaries increased in real terms between 20012013. Second, a similar pattern happened in the informal sector with high-skilled workers reducing their mean income per capita and low-skilled workers increasing it (see Table 4). Since salaries are higher in the formal sector, it should be more likely for a worker to get out of poverty by working in this sector rather than in the informal one. This hypothesis deserves further research and there could be other explanations behind the importance of formal sector income distribution dynamics for not just inequality reduction but also poverty declines. 
Table 4. Real Labor Income per Capita (in Real Bs. and Growth Rate)

\begin{tabular}{|c|c|c|c|c|c|c|c|}
\hline & & \multicolumn{2}{|c|}{2001} & \multicolumn{2}{|c|}{2006} & \multicolumn{2}{|c|}{2013} \\
\hline & & $\begin{array}{l}\text { Mean Labor } \\
\text { Income (Bs.) }\end{array}$ & $\begin{array}{l}\text { Share of workers } \\
\text { (percent) }\end{array}$ & $\begin{array}{l}\text { Labor Income } \\
\text { growth rate } \\
\text { respect to } \\
2001 \text { (percent) }\end{array}$ & $\begin{array}{l}\text { Share of workers } \\
\text { (percent) }\end{array}$ & $\begin{array}{l}\text { Labor Income } \\
\text { growth rate } \\
\text { respect to } 2001 \\
\text { (percent) }\end{array}$ & $\begin{array}{l}\text { Share of workers } \\
\text { (percent) }\end{array}$ \\
\hline \multirow{7}{*}{ Formal } & No education & 391 & 0 & 48 & 0 & 109 & 0 \\
\hline & Educ $1-3$ years & 1873 & 2 & -49 & 1 & -12 & 2 \\
\hline & Educ 4-6 years & 1110 & 7 & 16 & 5 & 38 & 4 \\
\hline & Educ 7-9 years & 1147 & 6 & 5 & 5 & 52 & 3 \\
\hline & Educ $10-12$ years & 1338 & 20 & 11 & 19 & 17 & 17 \\
\hline & Educ $13-15$ years & 1966 & 24 & 1 & 16 & -14 & 17 \\
\hline & Educ More than 16 & 2870 & 40 & 0 & 53 & -24 & 57 \\
\hline \multirow{7}{*}{ Informal } & No education & 395 & 11 & 17 & 7 & 7 & 8 \\
\hline & Educ $1-3$ years & 565 & 17 & 5 & 11 & 19 & 13 \\
\hline & Educ 4-6 years & 711 & 25 & 16 & 20 & 44 & 20 \\
\hline & Educ $7-9$ years & 701 & 15 & 5 & 15 & 77 & 11 \\
\hline & Educ $10-12$ years & 868 & 21 & -1 & 31 & 49 & 29 \\
\hline & Educ $13-15$ years & 1166 & 6 & -6 & 7 & -3 & 11 \\
\hline & Educ More than 16 & 2157 & 5 & -6 & 10 & -23 & 8 \\
\hline
\end{tabular}

Source: IMF staff calculations based on INE Household Surveys.

In addition, it seems that the minimum wage had a similar broad impact on both the formal and informal sectors, supporting the existence of a lighthouse effect (see section III). Indeed, labor income grew materially during 2001-2013 at most educational levels in the informal sector. In both the informal and formal sector, real incomes actually fell significantly for the most educated group (see Table 4).

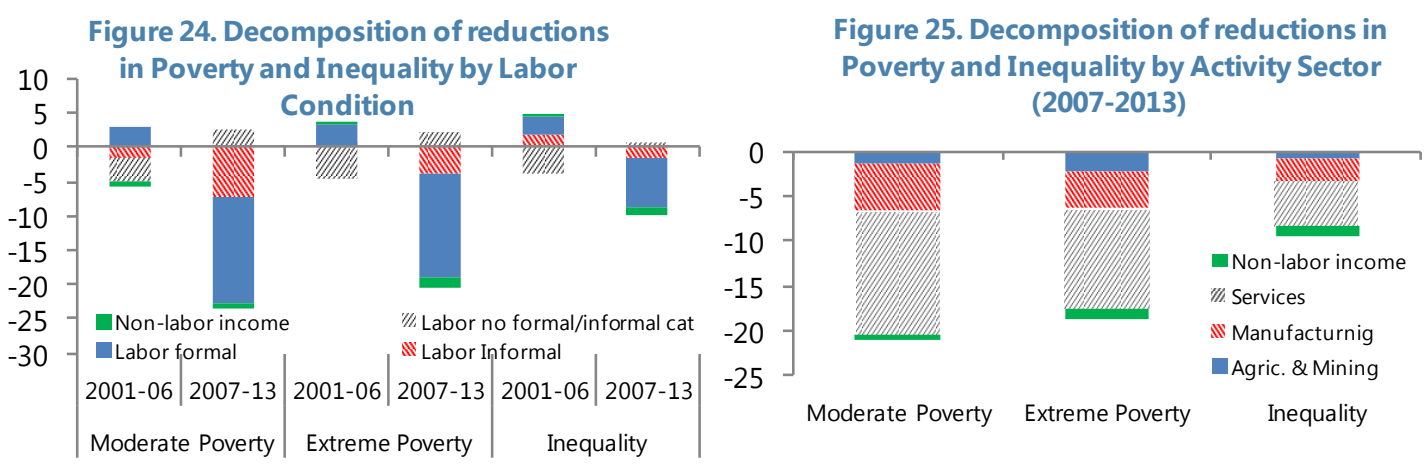

Finally, regarding changes in the distribution of productive sectors, Figure 25 suggests that changes in the services sector distribution explain most of the reduction in inequality and poverty, followed by the manufacturing sector, with these two sectors representing $3 / 4$ of the whole workforce. A strong currency and cheaper imports facilitating commerce and service sector activity could be an important reason behind this.

All the above decompositions confirm the importance of labor income in poverty/inequality reduction and a more limited role for non-labor income. Indeed, inequality reduced by 
0.10 percentage points between 2007-2013, of which just 0.01 p.p. was associated with changes in non-labor income. Extreme (moderate) poverty reduced by 19 (21) percentage points between 2007-2013, of which 17.4 (20.4) are explained changes in labor income; just 1.5 (0.6) percentage points are due to non-labor income changes.

\section{Wage Equations}

Finally, we estimate individual level wage equations as another lens through which to view inequality and poverty dynamics. In particular, we calculate an extended Mincer equation (Mincer, 1978) for three different years (2001, 2006 and 2013). The specification is as follows: ${ }^{17}$

$$
\ln \left(y_{i}\right)=\alpha+\beta X_{i}+\gamma_{1} \operatorname{Exp}_{i}+\gamma_{2} \operatorname{Exp}_{i}^{2}
$$

Where $y_{i}$ is labor income of individual $i, X_{i}$ represents a set of individual characteristics (gender, rural/urban area, education, age, labor condition, productive sector), and $E x p_{i}$ stands for work experience. Thus, this exercise identifies individual, regional and productive characteristics behind labor income of the working population, and permits to show some trends in their relative importance (see Table 5).

25. Decompositon of Reductions in Poverty and Inequality by Activity Sector It is worth noting that the mean of monthly real labor income grew by around 5 percent between 2001-2006, and almost 25 percent between 2006-2013. In order to facilitate the analysis, the constant and coefficients are normalized. They reflect variations from the benchmark average worker (i.e., an average urban worker living in Chuquisaca, with no formal education, between 15-20 years old, and working in agriculture \& mining in the formal sector).

The departments where labor income is higher than in other regions are Beni, Tarija, Santa Cruz and Pando, ${ }^{18}$ with Santa Cruz being the most important in terms of population. We could not find significant coefficients by age group (not reported - might be captured by experience). With regard to educational levels, and after controlling for other personal characteristics, there is evidence that returns on education are positive, but the skills premium (the salary gap between skilled and low-skilled workers) has diminished during the past 15 years. Labor income in manufacturing and service sectors is also higher with respect to the agriculture \& mining sectors. The manufacturing sector has higher salaries than in the

\footnotetext{
${ }^{17}$ Table 5 shows two sets of results, a simple OLS Mincer equation, and a Heckman sample-selection model which controls for selection bias due to non-included workers (workers with labor income equal to zero).

${ }^{18}$ Pando experienced a large increase in labor income in 2006 and 2013. However, we could not find any economic reason supporting that result. Changes in the sampling method or the small weight of Pando in the household survey should not be discarded as potential explanations.
} 
services sector but it is smaller in terms of number of workers (17 percent of workers compared to almost 50 percent of workers in the services sector).

Table 5. Econometric Model-(Mincer Equation for 2001, 2006, and 2013) 1/

\begin{tabular}{|c|c|c|c|c|c|c|c|}
\hline & & OLS & & & Heckman & & $\begin{array}{l}\text { Proportion } \\
\text { of workers in } 2013 \\
\text { (percentage) }\end{array}$ \\
\hline & (1) & (2) & (3) & (4) & (5) & (6) & \\
\hline VARIABLES & 2001 & 2006 & 2013 & 2001 & 2006 & 2013 & \\
\hline $\mathrm{La} \mathrm{Paz} \mathrm{2/}$ & $0.02 * *$ & $-0.044 * * *$ & $0.018 * * *$ & $0.022 * *$ & $-0.043 * * *$ & $0.02 * *$ & 26.7 \\
\hline Cochabamba 2/ & $0.047 * * *$ & 0.010 & $0.062 * * *$ & $0.051 * * *$ & 0.010 & $0.063 * * *$ & 17.5 \\
\hline Oruro 2/ & $-0.016 * * *$ & -0.076 & 0.042 & $-0.017 * * *$ & -0.077 & 0.042 & 4.8 \\
\hline Potosi 2/ & $-0.047 * * *$ & -0.012 & $-0.004 * * *$ & $-0.047 * * *$ & -0.010 & $-0.004 * * *$ & 8.2 \\
\hline Tarija 2/ & $0.098 * * *$ & 0.032 & $0.106^{* * *}$ & $0.103 * * *$ & $0.033 * *$ & $0.109 * * *$ & 4.9 \\
\hline Santa Cruz 2/ & $0.091 * * *$ & $0.041 * * *$ & $0.11 * * *$ & $0.096 * * *$ & $0.043 * * *$ & $0.11 * * *$ & 27.0 \\
\hline Beni 2/ & $0.087 * * *$ & 0.010 & $0.097 * * *$ & $0.094 * * *$ & $0.012 * * *$ & $0.098 * * *$ & 4.1 \\
\hline Pando 2/ & $0.058 * *$ & $0.09 * *$ & $0.13 * * *$ & $0.062 * * *$ & $0.091 * * *$ & $0.131 * * *$ & 1.1 \\
\hline Rural 2/ & $-0.064 * * *$ & $-0.032 * * *$ & $-0.057 * * *$ & $-0.067 * * *$ & -0.036 & $-0.059 * * *$ & 32.6 \\
\hline Educ 1-3 years 2/ & $0.044 * * *$ & $0.044 * * *$ & $0.055 * * *$ & $0.047 * * *$ & $0.045^{* *}$ & $0.055 * * *$ & 14.0 \\
\hline Educ 4-6 years 2/ & $0.094 * * *$ & $0.068 * * *$ & $0.112 * * *$ & $0.099 * * *$ & $0.07 * * *$ & $0.112 * * *$ & 18.0 \\
\hline Educ 7-9 years 2/ & $0.113 * * *$ & $0.064 * * *$ & $0.139 * * *$ & $0.12 * * *$ & $0.067 * *$ & $0.14 * * *$ & 8.2 \\
\hline Educ $10-12$ years $2 /$ & $0.129 * * *$ & $0.093 * * *$ & $0.137 * * *$ & $0.137 * * *$ & $0.096 * * *$ & $0.138 * * *$ & 22.3 \\
\hline Educ $13-15$ years $2 /$ & $0.181 * * *$ & $0.132 * * *$ & $0.125 * * *$ & $0.193 * * *$ & $0.136 * * *$ & $0.127 * * *$ & 13.8 \\
\hline Educ More than 16 2/ & $0.252 * * *$ & $0.19 * * *$ & $0.165 * * *$ & $0.266 * * *$ & $0.194 * * *$ & $0.168 * * *$ & 12.8 \\
\hline Experience & $0.011 * * *$ & $0.005 * *$ & $0.005 * * *$ & $0.013 * * *$ & $0.005^{*}$ & $0.006 * * *$ & \\
\hline Experience $^{\wedge} 2$ & $-0.00 * * *$ & $-0.00 * * *$ & $-0.00 * * *$ & $-0.00 * * *$ & $-0.00 * *$ & $-0.00 * * *$ & \\
\hline Manufacturing 2/ & & $0.019 *$ & $0.082 * * *$ & & 0.019 & $0.083 * * *$ & 16.9 \\
\hline Services 2/ & & 0.012 & $0.048 * * *$ & & 0.012 & $0.048 * * *$ & 48.2 \\
\hline Informal 2/ & $-0.103 * * *$ & $-0.107 * * *$ & $-0.088 * * *$ & $-0.107 * * *$ & $-0.108 * * *$ & $-0.088 * * *$ & \\
\hline Constant & 1.00 & 1.00 & 1.00 & 1.00 & 1.00 & 1.00 & \\
\hline Adjusted R-squared & 0.29 & 0.29 & 0.33 & & & & \\
\hline \multicolumn{8}{|l|}{ Mean of Monthly Real } \\
\hline Labor Income (Bs.) & 974 & 1048 & 1310 & 974 & 1048 & 1310 & \\
\hline \multicolumn{8}{|c|}{$* * * \mathrm{p}<0.01, * * \mathrm{p}<0.05, * \mathrm{p}<0.1$} \\
\hline \multicolumn{8}{|c|}{$1 /$ The LHS variable is the log of real income labor (CPI base year $2000=100$ ). } \\
\hline \multicolumn{8}{|c|}{$\begin{array}{l}2 / \mathrm{dy} / \mathrm{dx} \text { is for discrete change of dummy variable from } 0 \text { to } 1 \text {. The constant captures the mean income (re-scaled) of } \\
\text { urban workers in Chuquisaca with no formal education, and age between } 15 \text { to } 20 \text { years, working in Agriculture \& } \\
\text { Mining in the formal sector.. }\end{array}$} \\
\hline
\end{tabular}

Finally, workers in the informal sector have a lower labor income than those working in the formal sector but that difference reduced during 2001-2013 in a statistically significant way (i.e., the labor income gap between formal and informal sector is closing). According to the coefficients in Table A2 (appendix), the ratio of formal to informal salaries was around 1.8 in 2001 , but reduced to 1.6 in 2013 . Thus, in general, our previous results are supported by the individual-level wage equation estimates. 


\section{Conclusions}

Bolivia's has registered tremendous reductions in inequality and poverty since 2000. However, levels of both are still around or above the average for LA, and significantly above the numbers observed in AEs. Given this, a correct identification of the determinants behind the reductions is key to sustaining improvements into the future.

Bolivia increased its GDP by 80 percent in real terms during 2000-2014, in part reflecting the commodity boom. The real minimum wage increased by 100 percent during the same period, with average real labor income also rising by 40 percent. Remittances rose until 2007 when they peaked at around 8 percent of GDP; as of 2014, they were around 3.5 percent of GDP. Active social and economic policies were also put in place. The main three redistributive tools (Renta Dignidad, Bono Juancito Pinto and Bono Juana Azurduy) reached around 30 percent of the population, corresponding to $1 \frac{1}{2}$ percent of GDP of cash transfers in 2014.

The Gini coefficient dropped steadily during 2000-2013, with the decline gaining momentum during 2007-2011. Estimates of poverty show similar trends. Our findings suggest that inequality and poverty reduction was driven more by changes in labor income rather than changes in non-labor income. Low-skilled workers benefited more from higher labor income earnings, and the gains were concentrated in the informal sector. On the other hand, skilled workers, mainly concentrated in the formal sector, faced lower real salaries, thus reducing the skills premium in the overall economy. At the sectoral level, the manufacturing and services sectors registered higher labor income growth, although in the informal sector. Finally, Beni, Santa Cruz and Tarija were the departments which registered the strongest labor income growth.

Regarding non-labor income, its contribution to reducing inequality and poverty was positive, although small relative to the contribution of labor income. We find strong evidence, however, that its effect was important for specific target populations. Indeed, the number of persons with positive non-labor income increased markedly between 2006 and 2013, with effects concentrated in the elderly (Renta Dignidad) and youngest population groups (Bono Juana Azurduy and Bono Juancito Pinto). And the overall share of government transfers in household income has doubled since 2006.

Looking ahead, the skills premium could well increase as the spillovers to low skill workers from the commodity boom go into reverse. Given a tighter revenue envelope, it will be essential to ensure that labor and social policies are well designed and targeted. 


\section{References}

Azevedo, Joao Pedro \& Davalos, Maria Eugenia \& Diaz-Bonilla, Carolina \& Atuesta, Bernardo \& Castaneda, Raul Andres, 2013, "Fifteen years of inequality in Latin America: how have labor markets helped ?," Policy Research Working Paper 6384 (Washington: World Bank).

Azevedo, Joao Pedro \& Gabriela Inchauste, \& Viviane Sanfelice, 2013, "Decomposing the Recent Inequality Decline in Latin America," Policy Research Working Paper 6315 (Washington: The World Bank).

Barros, Ricardo \& Mirela Carvalho \& Samuel Franco \& Rosane Mendonça, 2006, "Uma Análise das Principais Causas da Queda Recente na Desigualdade de Renda Brasileira," No 1203, Discussion Papers, Instituto de Pesquisa Econômica AplicadaIPEA.

Boeri, Tito \& Garibaldi, Pietro \& Ribeiro, Marta, 2010, "Behind the Lighthouse Effect," IZA Discussion Papers 4890, Institute for the Study of Labor (IZA).

Bosch, Mariano \& Jarret Guajardo, 2012, "Labor Market Impacts of Non-Contributory Pensions: The Case of Argentina's Moratorium," IDB Working Paper 78158 (Washington: Inter-American Development Bank).

Bourguignon Francois, 2004."The Poverty-growth-inequality triangle," Indian Council for Research on International Economic Relations, New Delhi Working Papers 125, Indian Council for Research on International Economic Relations, New Delhi, India.

Celhay, Pablo A. \& Gertler, Paul J. \& Giovagnoli, Paula \& Vermeersch, Christel M. J., 2015, "Long-run effects of temporary incentives on medical care productivity," Policy Research Working Paper 7348 (Washington: World Bank).

Cornia, Giovanni Andrea, 2012, "Inequality Trends and their Determinants: Latin America over 1990-2011," Working Paper No. 009 (Helsinki: World Institute for Development Economic Research United Nations University).

Datt, G. and M. Ravallion, 1992, "Growth and Redistribution Components of Changes in Poverty Measures: A Decomposition with Applications to Brazil and India in the 1980s." Journal of Development Economics, Vol. 38, pp. 275-295.

Datt, G. and Ravallion, M., 2002. "Is India's Economic Growth Leaving the Poor Behind?", Journal of Economic Perspectives 16 (3): 89-108.

De la Torre, Augusto \& Levy Yeyati, Eduardo \& Beylis, Guillermo \& Didier, Tatiana \& Rodriguez Castelan, Carlos \& Schmukler, Sergio, 2014, "Inequality in a Lower Growth Latin America: LAC Semiannual Report," (Washington: World Bank).

Fan, S., Hazell, P. and Thorat, S., 1999. "Linkages Between Government Spending, Growth and Poverty in Rural India," Research Report 110. Washington, DC: IFPRI.

Garriga Santiago, 2014,"Impacto del Plan Nacer sobre la Mortalidad Infantil en Argentina," Centro de Estudios, Laborales y Sociales, Working Papers 0168, (La Plata: Universidad Nacional de La Plata). 
Gasparini, Leonardo \& Galiani, Sebastian \& Cruces, Guillermo \& Acosta, Pablo A., 2011, "Educational Upgrading and Returns to Skills in Latin America: Evidence from a Supply-Demand Framework, 1990-2010," IZA Discussion Papers 6244, (Bonn: Institute for the Study of Labor).

Gertler, Paul \& Giovagnoli, Paula \& Martinez, Sebastian, 2014, "Rewarding provider performance to enable a healthy start to life: evidence from Argentina's Plan Nacer," Policy Research Working Paper 6884 (Washington: World Bank).

Khamis, Melanie, 2008, "Does the Minimum Wage Have a Higher Impact on the Informal than on the Formal Labor Market? Evidence from Quasi-Experiments," IZA Discussion Papers 3911 (Bonn: Institute for the Study of Labor).

Lustig, Nora \& Lopez-Calva, Luis F. \& Ortiz-Juarez, Eduardo, 2013, "Deconstructing the decline in inequality in Latin America," Policy Research Working Paper 6552, (Washington: World Bank).

Maloney, William F. \& Nunez, Jairo \& Cunningham, Wendy \& Fiess, Norbert \& Montenegro, Claudio \& Murrugarra, Edmundo \& Santamaria,Mauricio \& Sepulveda, Claudia, 2001, "Measuring the impact of minimum wages: evidence from Latin America," Policy Research Working Paper 2597 (Washington: World Bank).

Mincer, J., 1974, "Schooling, Experience and Earnings," (New York: National Bureau of Economic Research).

OECD, 2011. “Divided We Stand: Why Inequality Keeps Rising," OECD Publishing, Paris.

Ostry, Jonathan David \& Berg, Andrew \& Tsangarides, Charalambos G., 2014, "Redistribution, Inequality, and Growth," IMF Staff Discussion Notes 14/02 (Washington: International Monetary Fund).

Ravallion, Martin, 2001."Growth, Inequality and Poverty: Looking Beyond Averages," World Development, Elsevier, vol. 29(11), pages 1803-1815, November.

Sastre, Mercedes \& Trannoy, Alain, 2002, "Shapley inequality decomposition by factor components: Some methodological issues", Journal of Economics, 9, issue 1, p. 5189.

Solt, Frederick, 2009, "Standardizing the World Income Inequality Database," Social Science Quarterly, Southwestern Social Science Association, Vol. 90(2), pp. 231-242.

UDAPE, 2013, “El Impacto de la Renta Dignidad,” Ministerio de Planificación del Desarrollo, Bolivia. 


\section{Appendix 1. Description of Inequality Indicators}

- Theil Index.

The Theil index is a statistic used to measure economic inequality. The basic Theil index TT is the same as redundancy in information theory which is the maximum possible entropy of the data minus the observed entropy. It is a special case of the generalized entropy index. It can be viewed as a measure of redundancy, lack of diversity, isolation, segregation, inequality, non-randomness.

If everyone has the same income, then TT gives 0 which, counter-intuitively, is when the population's income has maximum disorder. If one person has all the income, then TT gives the result $\ln (N)$, which is maximum order. Dividing TT by $\ln (N)$ can normalize the equation to range from 0 to 1 .

$$
T T=\frac{1}{N} \sum_{i=1}^{N}\left(\frac{y_{i}}{\mu} \cdot \ln \frac{y_{i}}{\mu}\right)
$$

Where $y_{i}$ is individual income $(\mathrm{i}=1 . . \mathrm{N})$ and $\mu$ is the mean income.

\section{- The Atkinson index}

The Atkinson index is a measure of income inequality developed by Anthony Barnes Atkinson. The index can be turned into a normative measure by imposing a coefficient $\varepsilon$ to weight incomes. Greater weight can be placed on changes in a given portion of the income distribution by choosing $\varepsilon$, the level of "inequality aversion", appropriately. The Atkinson index becomes more sensitive to changes at the lower end of the income distribution as $\varepsilon$ approaches 1. Conversely, as the level of inequality aversion falls (that is, as $\varepsilon$ approaches 0 ) the Atkinson becomes more sensitive to changes in the upper end of the income distribution.

The Atkinson $\varepsilon$ parameter is often called the "inequality aversion parameter", since it quantifies the amount of social utility that is assumed to be gained from complete redistribution of resources. For $\varepsilon=0$, (no aversion to inequality) it is assumed that no social utility is gained by complete redistribution and the Atkinson index $\left(A_{\varepsilon}\right)$ is zero. For $\varepsilon=\infty$ (infinite aversion to inequality), it is assumed that infinite social utility is gained by complete redistribution in which case $\left(A_{\varepsilon}\right)=1$. The Atkinson index $\left(A_{\varepsilon}\right)$ then varies between 0 and 1 and is a measure of the amount of social utility to be gained by complete redistribution of a given income distribution.

$$
A_{\varepsilon}=\left\{\begin{array}{cc}
1-\frac{1}{\mu}\left(\frac{1}{N} \sum_{i=1}^{N} y_{i}^{1-\varepsilon}\right)^{1 /(1-\varepsilon)} & \text { for } 0 \leq \varepsilon \neq 1 \\
1-\frac{1}{\mu}\left(\prod_{i=1}^{N} y_{i}\right)^{1 / N} & \text { for } \varepsilon=1
\end{array}\right.
$$

Where $y_{i}$ is individual income $(\mathrm{i}=1 . . \mathrm{N})$ and $\mu$ is the mean income. 
Figure A1. Bolivia: Monthly Real Labor Income per capita (Bs.)

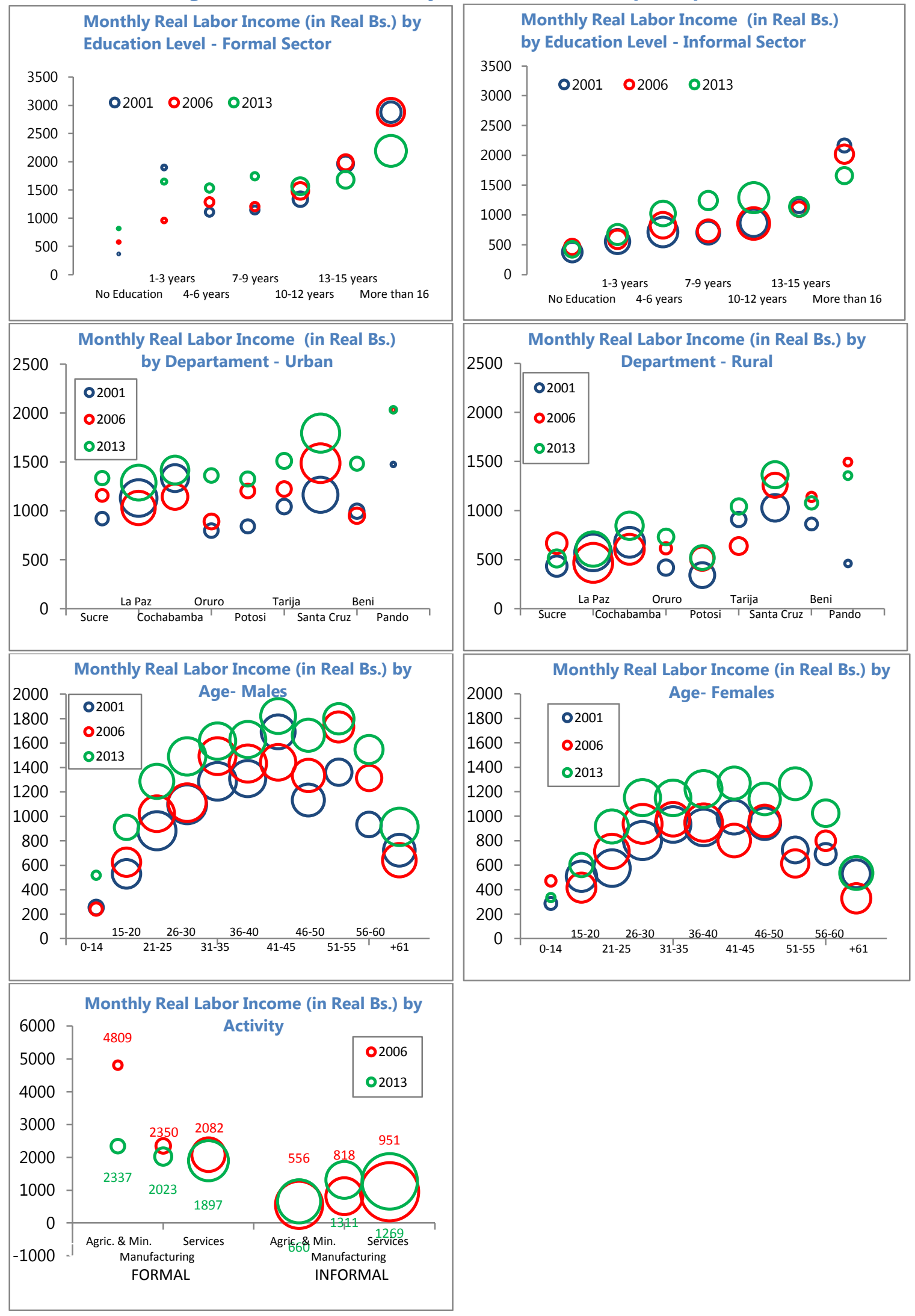


Figure A2. Bolivia: Monthly Real Non-Labor Income per Capita (Bs.)

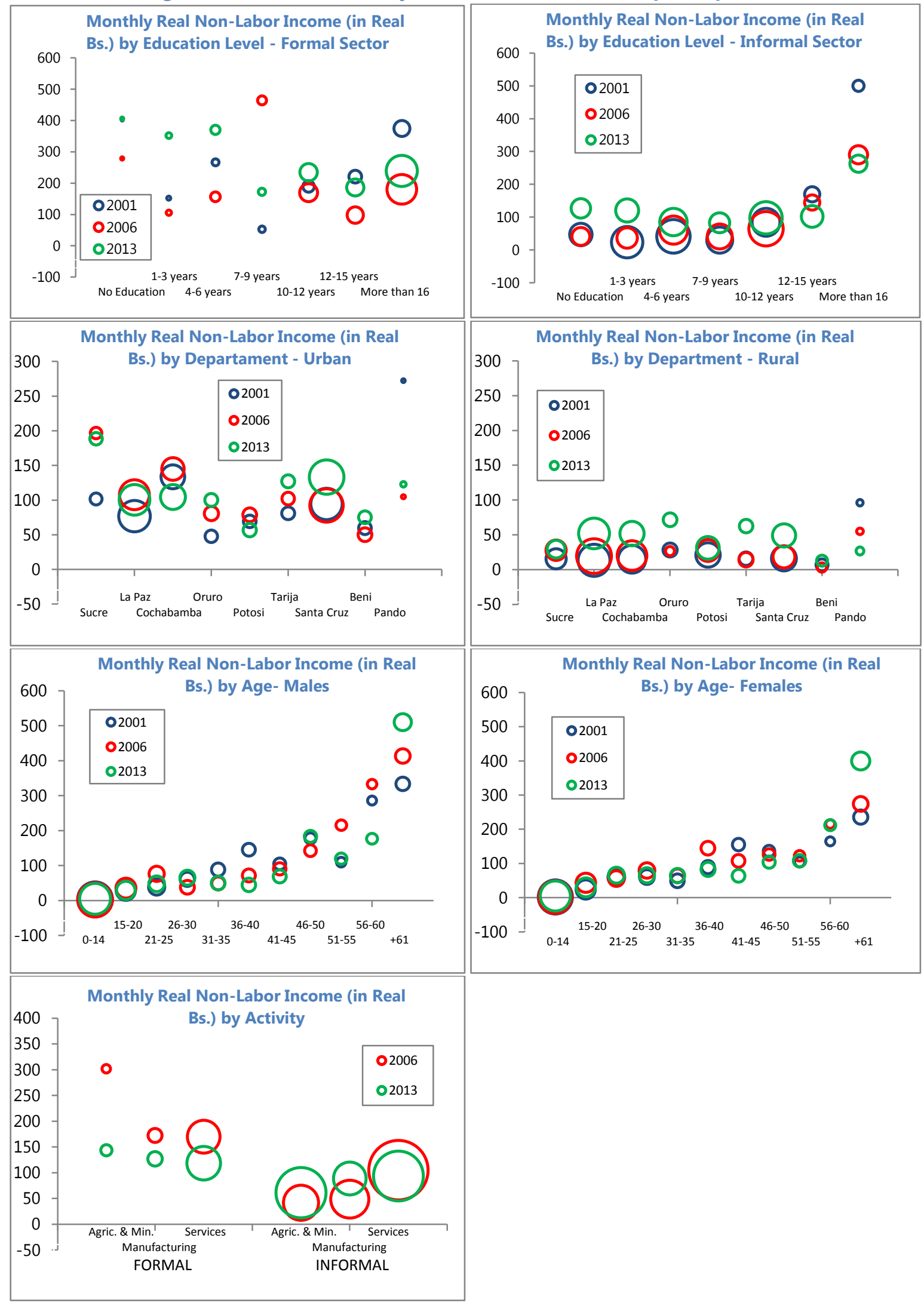


Table A1. Poverty Headcount Ratio

Estimations based on harmonized income - SEDLAC (CEDLAS and the World Bank)

\begin{tabular}{|c|c|c|c|c|c|c|c|c|c|}
\hline \multirow[b]{2}{*}{ Year } & \multicolumn{3}{|c|}{ National } & \multicolumn{3}{|c|}{ Urban } & \multicolumn{3}{|c|}{ Rural } \\
\hline & $\begin{array}{c}\text { Global } \\
\text { Extreme } \\
\text { Poor } \\
\text { (\$1.25 a } \\
\text { day) }\end{array}$ & $\begin{array}{c}\text { Extreme } \\
\text { Poor } \\
\text { (\$2.50 a } \\
\text { day) }\end{array}$ & $\begin{array}{c}\text { Poor(\$4 a } \\
\text { day) }\end{array}$ & $\begin{array}{c}\text { Global } \\
\text { Extreme } \\
\text { Poor } \\
\text { (\$1.25 a } \\
\text { day) }\end{array}$ & $\begin{array}{c}\text { Extreme } \\
\text { Poor } \\
\text { (\$2.50 a } \\
\text { day) }\end{array}$ & $\begin{array}{c}\text { Poor(\$4 a } \\
\text { day) }\end{array}$ & $\begin{array}{c}\text { Global } \\
\text { Extreme } \\
\text { Poor } \\
\text { (\$1.25 a } \\
\text { day) }\end{array}$ & $\begin{array}{c}\text { Extreme } \\
\text { Poor } \\
(\$ 2.50 \text { a } \\
\text { day })\end{array}$ & $\begin{array}{c}\text { Poor(\$4 a } \\
\text { day) }\end{array}$ \\
\hline 2000 & 27.2 & 43.3 & 59.9 & 8.9 & 25.1 & 45.3 & 60.5 & 76.5 & 86.6 \\
\hline 2001 & 21.4 & 38.3 & 56.3 & 6.8 & 22.4 & 42.2 & 46.8 & 66.0 & 80.9 \\
\hline 2002 & 22.0 & 39.7 & 57.8 & 6.5 & 22.4 & 42.9 & 48.9 & 69.8 & 83.5 \\
\hline $\begin{array}{l}2003 \\
2004\end{array}$ & \multicolumn{9}{|c|}{ Survey not Comparable } \\
\hline 2005 & 18.3 & 35.0 & 53.7 & 4.3 & 19.4 & 40.2 & 43.3 & 62.8 & 77.6 \\
\hline 2006 & 15.7 & 32.0 & 48.5 & 3.2 & 15.3 & 33.6 & 38.9 & 62.9 & 76.2 \\
\hline 2007 & 12.0 & 30.3 & 47.4 & 2.4 & 17.7 & 34.9 & 31.0 & 55.3 & 72.2 \\
\hline 2008 & 10.5 & 22.8 & 40.4 & 3.5 & 12.3 & 29.1 & 23.7 & 42.9 & 61.7 \\
\hline 2009 & 10.7 & 20.6 & 35.1 & 2.9 & 9.8 & 23.6 & 25.7 & 41.7 & 57.5 \\
\hline 2010 & \multicolumn{9}{|c|}{ No survey this year } \\
\hline 2011 & 7.0 & 16.1 & 29.0 & 1.5 & 7.0 & 18.1 & 17.9 & 34.4 & 51.0 \\
\hline 2012 & 8.2 & 17.1 & 29.2 & 1.8 & 7.8 & 18.6 & 21.1 & 35.9 & 50.4 \\
\hline 2013 & 6.8 & 14.4 & 27.2 & 1.2 & 6.0 & 15.3 & 18.0 & 31.8 & 51.4 \\
\hline
\end{tabular}

Source: LAC Equity Lab tabulations of SEDLAC (CEDLAS and the World Bank)

Official estimations - UDAPE

\begin{tabular}{|c|c|c|c|c|c|c|}
\hline \multirow[b]{3}{*}{ Year } & \multicolumn{2}{|c|}{ National } & \multicolumn{2}{|c|}{ Urban } & \multicolumn{2}{|c|}{ Rural } \\
\hline & Extreme Poor & $\begin{array}{l}\text { Moderate } \\
\text { Poor }\end{array}$ & Extreme Poor & $\begin{array}{c}\text { Moderate } \\
\text { Poor }\end{array}$ & Extreme Poor & $\begin{array}{c}\text { Moderate } \\
\text { Poor }\end{array}$ \\
\hline & & & & & & \\
\hline 2000 & 45.2 & 66.4 & 27.9 & 54.5 & 75.0 & 87.0 \\
\hline 2001 & 38.8 & 63.1 & 26.2 & 54.3 & 59.7 & 77.7 \\
\hline 2002 & 39.5 & 63.3 & 25.7 & 53.9 & 62.3 & 78.8 \\
\hline 2003 & \multirow{2}{*}{\multicolumn{6}{|c|}{ Survey not Comparable }} \\
\hline 2004 & & & & & & \\
\hline 2005 & 38.2 & 60.6 & 24.3 & 51.1 & 62.9 & 77.6 \\
\hline 2006 & 37.7 & 59.9 & 23.4 & 50.3 & 62.2 & 76.5 \\
\hline 2007 & 37.7 & 60.1 & 23.7 & 50.9 & 63.9 & 77.3 \\
\hline 2008 & 30.1 & 57.3 & 18.9 & 48.7 & 51.5 & 73.6 \\
\hline 2009 & 26.1 & 51.3 & 16.1 & 43.5 & 45.5 & 66.4 \\
\hline 2010 & \multicolumn{6}{|c|}{ No survey this year } \\
\hline 2011 & 20.9 & 45.0 & 10.8 & 36.8 & 41.3 & 61.3 \\
\hline 2012 & 21.6 & 43.4 & 12.2 & 34.7 & 40.9 & 61.1 \\
\hline 2013 & \multicolumn{6}{|c|}{ Not published yet } \\
\hline
\end{tabular}


Table A2. Econometric Model-(Mincer Equation for 2001, 2006, and 2013) 1/

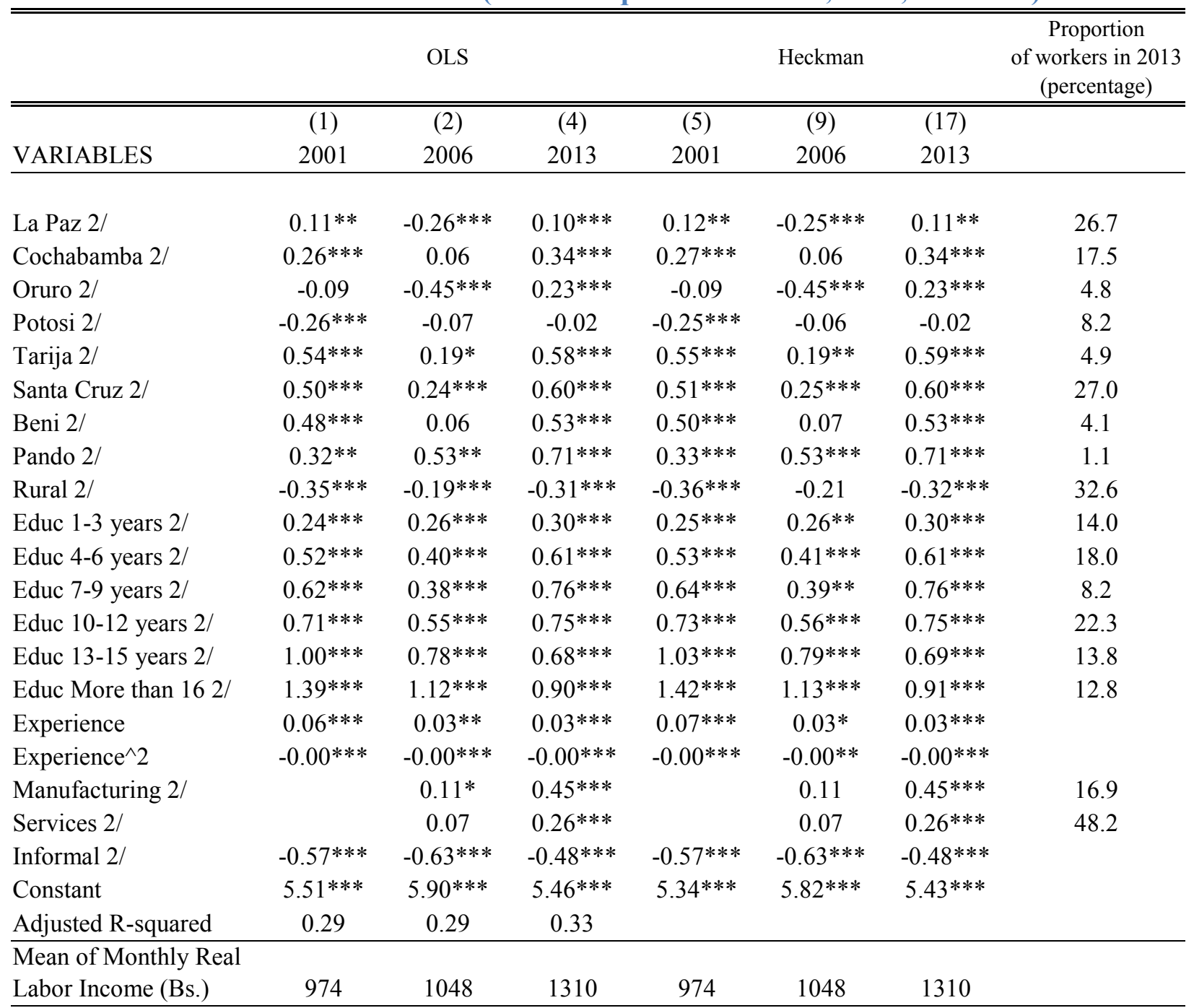

$* * * \mathrm{p}<0.01, * * \mathrm{p}<0.05, * \mathrm{p}<0.1$

$1 /$ The LHS variable is the log of real income labor (CPI base year 2000=100).

P-values calculated using robust standard errors.

$2 / \mathrm{dy} / \mathrm{dx}$ is for discrete change of dummy variable from 0 to 1 . The constant captures the mean income of urban workers in Chuquisaca with no formal education, and age between 15 to 20 years, working in Agriculture \& Mining sector. 